\title{
LEVEL II SCOUR ANALYSIS FOR BRIDGE 5 (DUMMVT00300005) on STATE ROUTE 30, crossing STICKNEY BROOK, DUMMERSTON, VERMONT
}

U.S. Geological Survey Open-File Report 97-627

Prepared in cooperation with

VERMONT AGENCY OF TRANSPORTATION and

FEDERAL HIGHWAY ADMINISTRATION 


\section{LEVEL II SCOUR ANALYSIS FOR BRIDGE 5 (DUMMVT00300005) on STATE ROUTE 30, crossing STICKNEY BROOK, DUMMERSTON, VERMONT \\ By MICHAEL A. IVANOFF}

U.S. Geological Survey Open-File Report 97-627

Prepared in cooperation with

VERMONT AGENCY OF TRANSPORTATION

and

FEDERAL HIGHWAY ADMINISTRATION 


\title{
U.S. DEPARTMENT OF THE INTERIOR BRUCE BABBITT, Secretary
}

\author{
U.S. GEOLOGICAL SURVEY \\ Gordon P. Eaton, Director
}

For additional information write to:

District Chief

U.S. Geological Survey 361 Commerce Way

Pembroke, NH 03275-3718
Copies of this report may be purchased from:

U.S. Geological Survey

Branch of Information Services

Open-File Reports Unit

Box 25286

Denver, CO 80225-0286 


\section{CONTENTS}

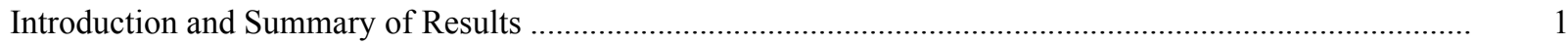

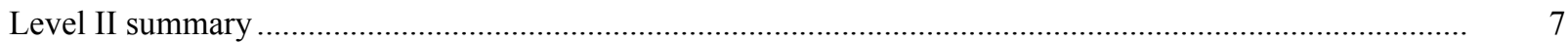

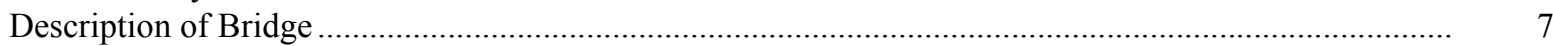

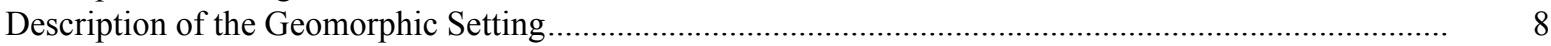

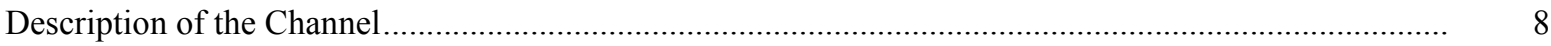

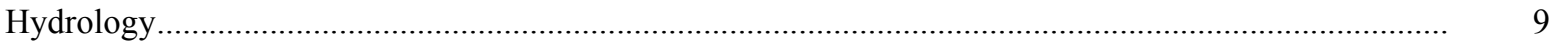

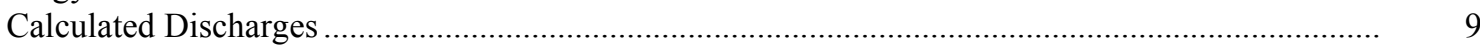

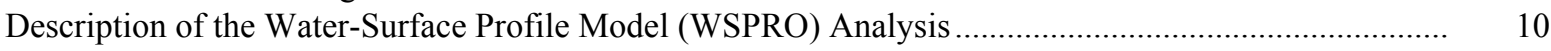

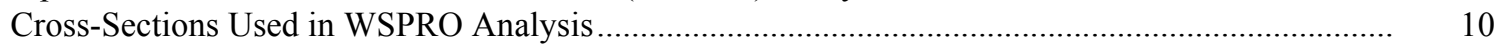

Data and Assumptions Used in WSPRO Model ...................................................................... 11

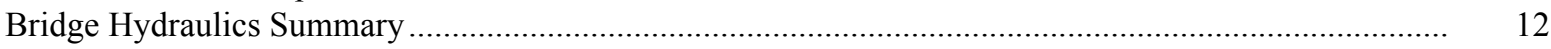

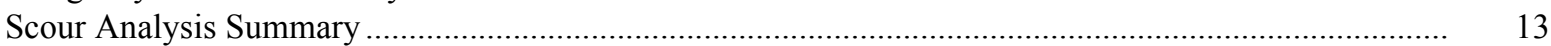

Special Conditions or Assumptions Made in Scour Analysis ...................................................... 13

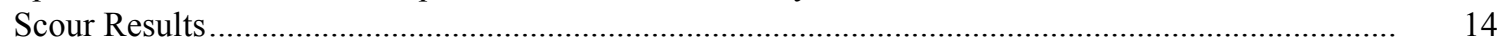

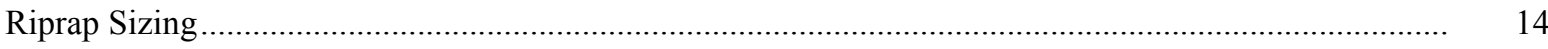

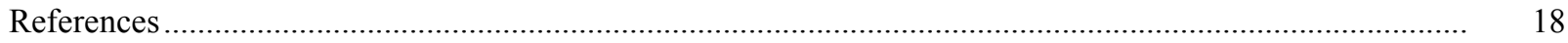

Appendixes:

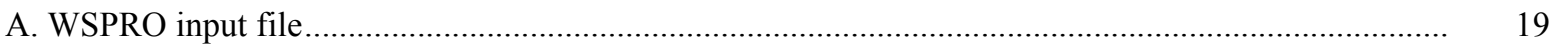



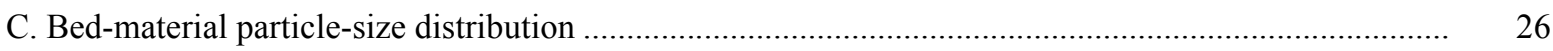

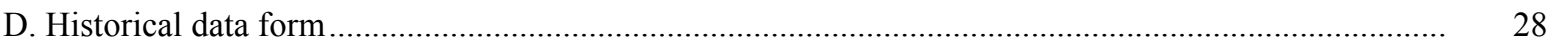

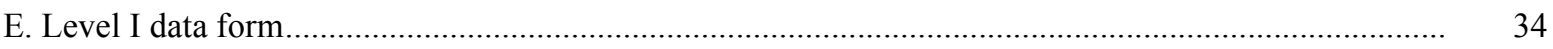

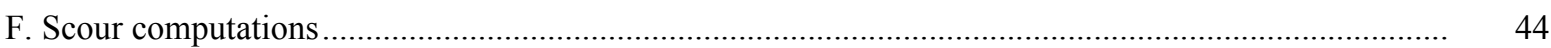

\section{FIGURES}

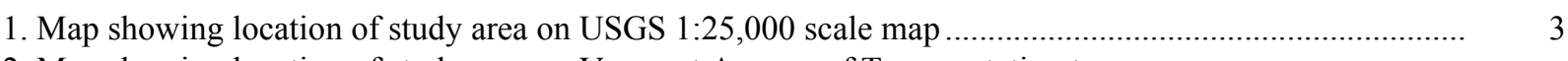

2. Map showing location of study area on Vermont Agency of Transportation town
highway map

3. Structure DUMMVT00300005 viewed from upstream (August 12, 1996)........................................... 5

4. Downstream channel viewed from structure DUMMVT00300005 (August 12, 1996)......................... 5

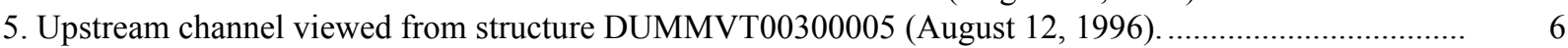

6. Structure DUMMVT00300005 viewed from downstream (August 12, 1996)..................................... 6

7. Water-surface profiles for the 100- and 500-year discharges at structure

DUMMVT00300005 on State Route 30, crossing Stickney Brook,

Dummerston, Vermont.

8. Scour elevations for the 100- and 500-year discharges at structure

DUMMVT00300005 on State Route 30, crossing Stickney Brook,

Dummerston, Vermont.

\section{TABLES}

1. Remaining footing/pile depth at abutments for the 100-year discharge at structure

DUMMVT00300005 on State Route 30, crossing Stickney Brook,

Dummerston, Vermont

2. Remaining footing/pile depth at abutments for the 500-year discharge at structure

DUMMVT00300005 on State Route 30, crossing Stickney Brook,

Dummerston, Vermont. 


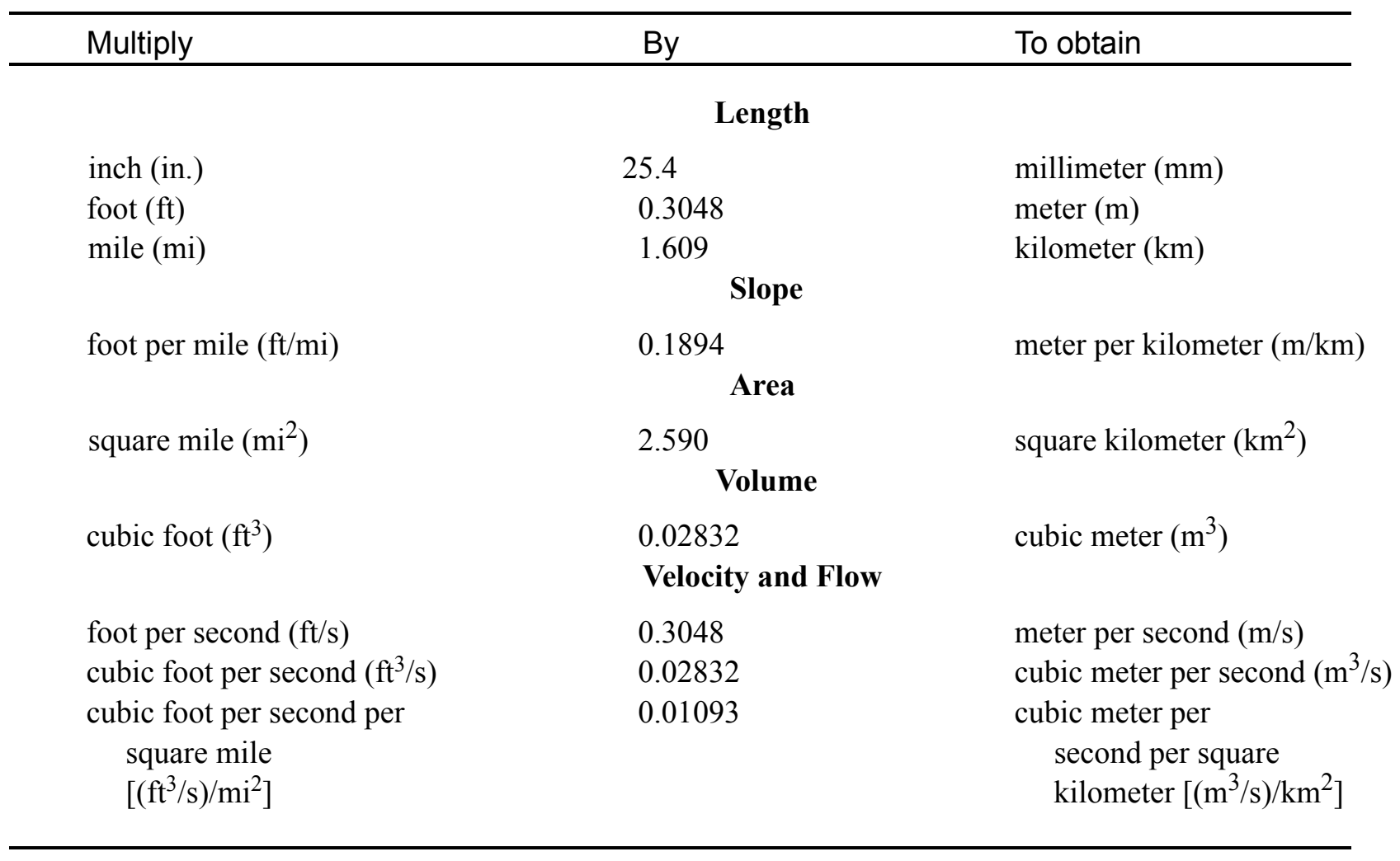

\section{OTHER ABBREVIATIONS}

$\begin{array}{lrlr}\mathrm{BF} & \text { bank full } & \text { LWW } & \text { left wingwall } \\ \mathrm{cfs} & \text { cubic feet per second } & \text { MC } & \text { main channel } \\ \mathrm{D}_{50} & \text { median diameter of bed material } & \text { RAB } & \text { right abutment } \\ \mathrm{DS} & \text { downstream } & \text { RABUT } & \text { face of right abutment } \\ \mathrm{elev} & \text { elevation } & \text { RB } & \text { right bank } \\ \mathrm{f} / \mathrm{p} & \text { flood plain } & \text { ROB } & \text { right overbank } \\ \mathrm{ft}^{2} & \text { square feet } & \text { RWW } & \text { right wingwall } \\ \mathrm{ft} / \mathrm{ft} & \text { feet per foot } & \text { TH } & \text { town highway } \\ \mathrm{JCT} & \text { junction } & \text { UB } & \text { under bridge } \\ \mathrm{LAB} & \text { left abutment } & \text { US } & \text { upstream } \\ \mathrm{LABUT} & \text { face of left abutment } & \text { USGS } & \text { United States Geological Survey } \\ \mathrm{LB} & \text { left bank } & \text { VTAOT Vermont Agency of Transportation } \\ \mathrm{LOB} & \text { left overbank } & \text { WSPRO } & \text { water-surface profile model }\end{array}$

In this report, the words "right" and "left" refer to directions that would be reported by an observer facing downstream. Sea level: In this report, "sea level" refers to the National Geodetic Vertical Datum of 1929-- a geodetic datum derived from a general adjustment of the first-order level nets of the United States and Canada, formerly called Sea Level Datum of 1929.

In the appendices, the above abbreviations may be combined. For example, USLB would represent upstream left bank. 


\title{
LEVEL II SCOUR ANALYSIS FOR BRIDGE 5 (DUMMVT00300005) ON STATE ROUTE 30, CROSSING STICKNEY BROOK, DUMMERSTON, VERMONT
}

\author{
By Michael A. Ivanoff
}

\section{INTRODUCTION AND SUMMARY OF RESULTS}

This report provides the results of a detailed Level II analysis of scour potential at structure DUMMVT00300005 on State Route 30 crossing Stickney Brook, Dummerston, Vermont (figures 1-8). A Level II study is a basic engineering analysis of the site, including a quantitative analysis of stream stability and scour (U.S. Department of Transportation, 1993). Results of a Level I scour investigation also are included in Appendix E of this report. A Level I investigation provides a qualitative geomorphic characterization of the study site. Information on the bridge, gleaned from Vermont Agency of Transportation (VTAOT) files, was compiled prior to conducting Level I and Level II analyses and is found in Appendix D.

The site is in the New England Upland section of the New England physiographic province in southeastern Vermont. The $6.31-\mathrm{mi}^{2}$ drainage area is in a predominantly rural and forested basin. In the vicinity of the study site, the surface cover is forest and brush.

In the study area, Stickney Brook has an incised, straight channel with a slope of approximately $0.04 \mathrm{ft} / \mathrm{ft}$, an average channel top width of $80 \mathrm{ft}$ and an average bank height of $7 \mathrm{ft}$. The channel bed material is predominantly cobble with a median grain size $\left(\mathrm{D}_{50}\right)$ of $80.3 \mathrm{~mm}(0.264 \mathrm{ft})$. The geomorphic assessment at the time of the Level I and Level II site visit on August 12, 1996, indicated that the reach was aggrading.

The State Route 30 crossing of Stickney Brook is a 84-ft-long, two-lane bridge consisting of one 82-foot steel-beam span (Vermont Agency of Transportation, written communication, March 30, 1995). The opening length of the structure parallel to the bridge face is $79.7 \mathrm{ft}$. The bridge is supported by vertical, concrete abutments with spill-through embankments. The channel is skewed approximately 5 degrees to the opening while the opening-skew-toroadway is 0 degrees.

A scour hole $0.5 \mathrm{ft}$ deeper than the mean thalweg depth was observed along the toe of the right spill-through slope during the Level I assessment. The scour protection measures at the site were type- 2 stone fill (less than 36 inches diameter) along the left and right bank under the bridge forming a spill-through slope and type- 2 stone fill from approximately 20 $\mathrm{ft}$ to $64 \mathrm{ft}$ upstream on the right bank. Additional details describing conditions at the site are included in the Level II Summary and Appendices D and E. 
Scour depths and recommended rock rip-rap sizes were computed using the general guidelines described in Hydraulic Engineering Circular 18 (Richardson and others, 1995). Total scour at a highway crossing is comprised of three components: 1) long-term streambed degradation; 2) contraction scour (due to accelerated flow caused by a reduction in flow area at a bridge) and; 3) local scour (caused by accelerated flow around piers and abutments). Total scour is the sum of the three components. Equations are available to compute depths for contraction and local scour and a summary of the results of these computations follows.

Contraction scour for all modelled flows ranged from 0.0 to $0.2 \mathrm{ft}$. The worst-case contraction scour occurred at the 100-year discharge. Left abutment scour ranged from 5.5 to $6.3 \mathrm{ft}$. Right abutment scour ranged from 2.0 to $3.8 \mathrm{ft}$. The worst-case abutment scour occurred at the 500-year discharge. Additional information on scour depths and depths to armoring are included in the section titled "Scour Results". Scoured-streambed elevations, based on the calculated scour depths, are presented in tables 1 and 2. A cross-section of the scour computed at the bridge is presented in figure 8. Scour depths were calculated assuming an infinite depth of erosive material and a homogeneous particle-size distribution.

It is generally accepted that the Froehlich equation (abutment scour) gives "excessively conservative estimates of scour depths" (Richardson and others, 1995, p. 47). Usually, computed scour depths are evaluated in combination with other information including (but not limited to) historical performance during flood events, the geomorphic stability assessment, existing scour protection measures, and the results of the hydraulic analyses. Therefore, scour depths adopted by VTAOT may differ from the computed values documented herein. 


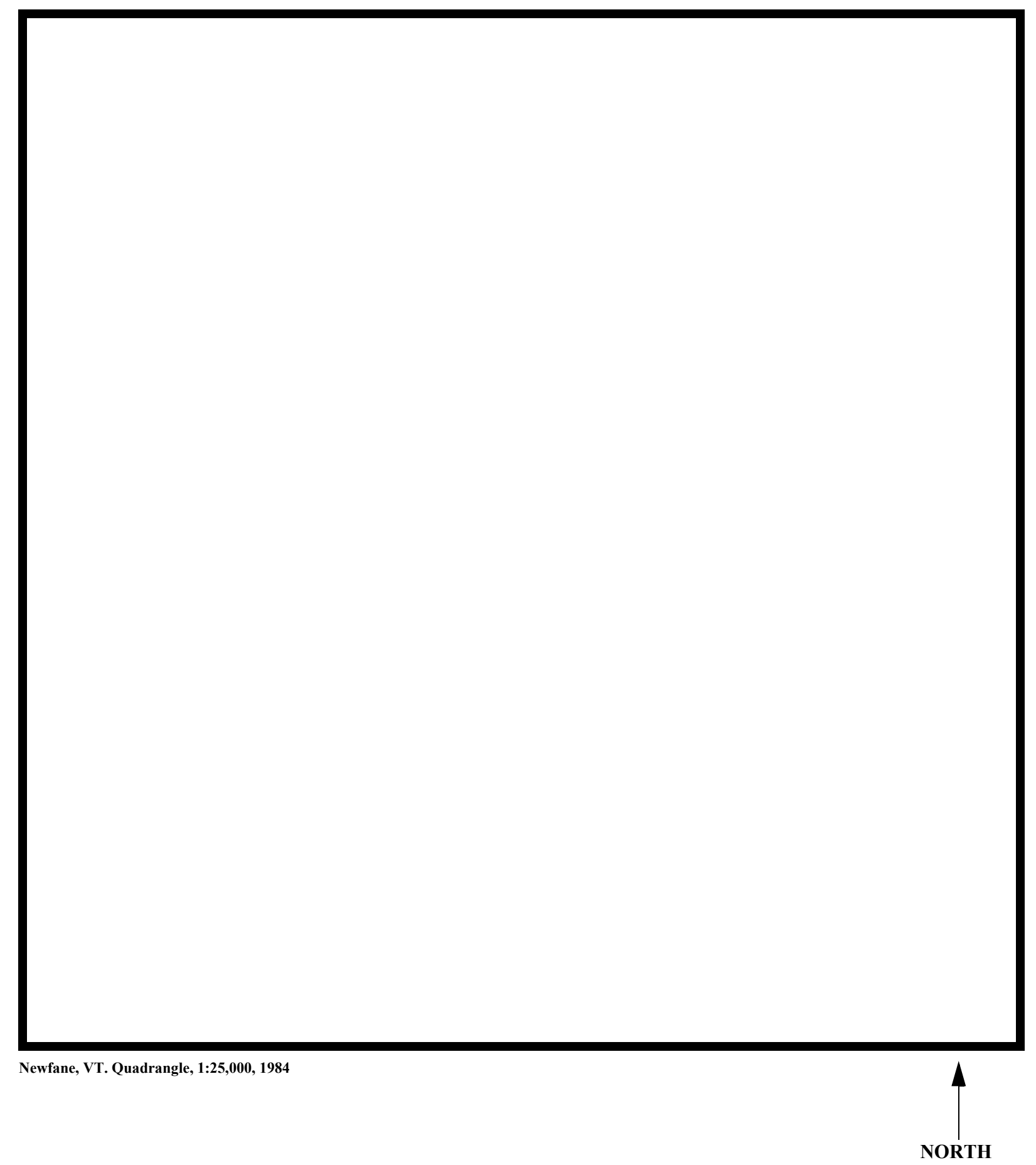

Figure 1. Location of study area on USGS 1:24,000 scale map. 
Figure 2. Location of study area on Vermont Agency of Transportation town highway map. 

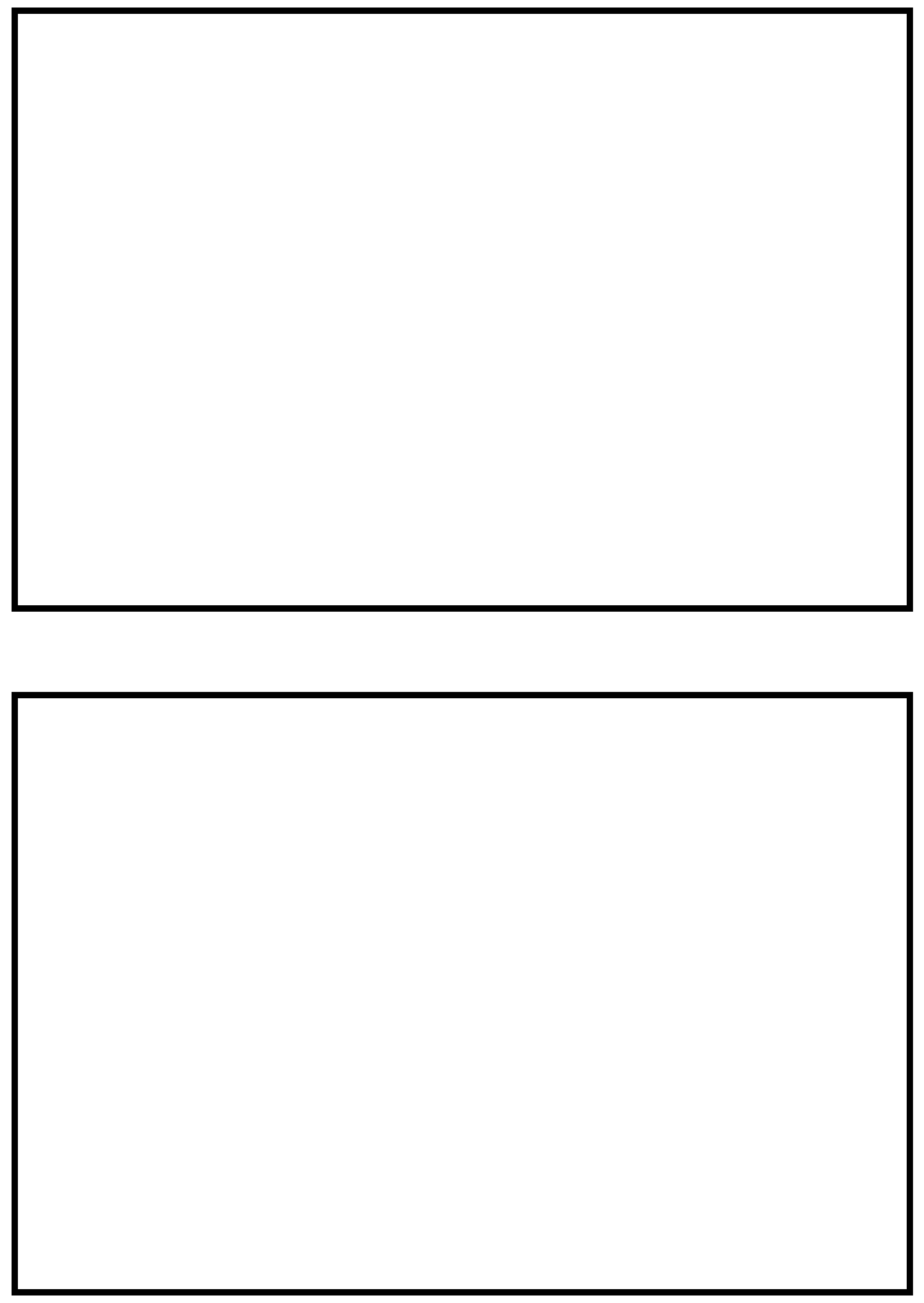

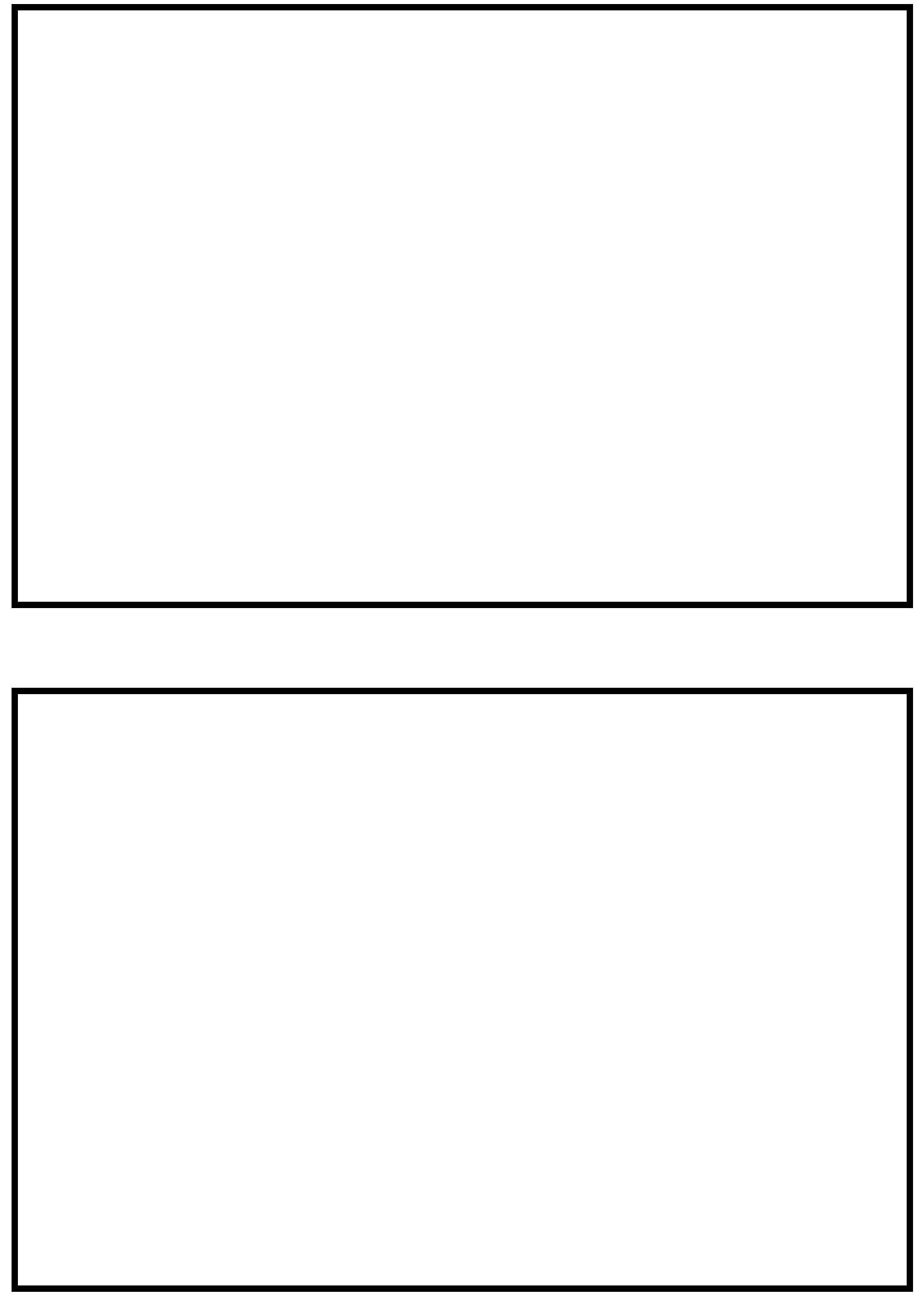


\section{LEVEL II SUMMARY}

\begin{tabular}{llllll} 
Structure Number & \multicolumn{2}{c}{ DUMMVT00300005 } & Stream & \multicolumn{3}{c}{ Stickney Brook } \\
& Wounty & Windham & RT 30 & District & 2
\end{tabular}

\section{Description of Bridge}

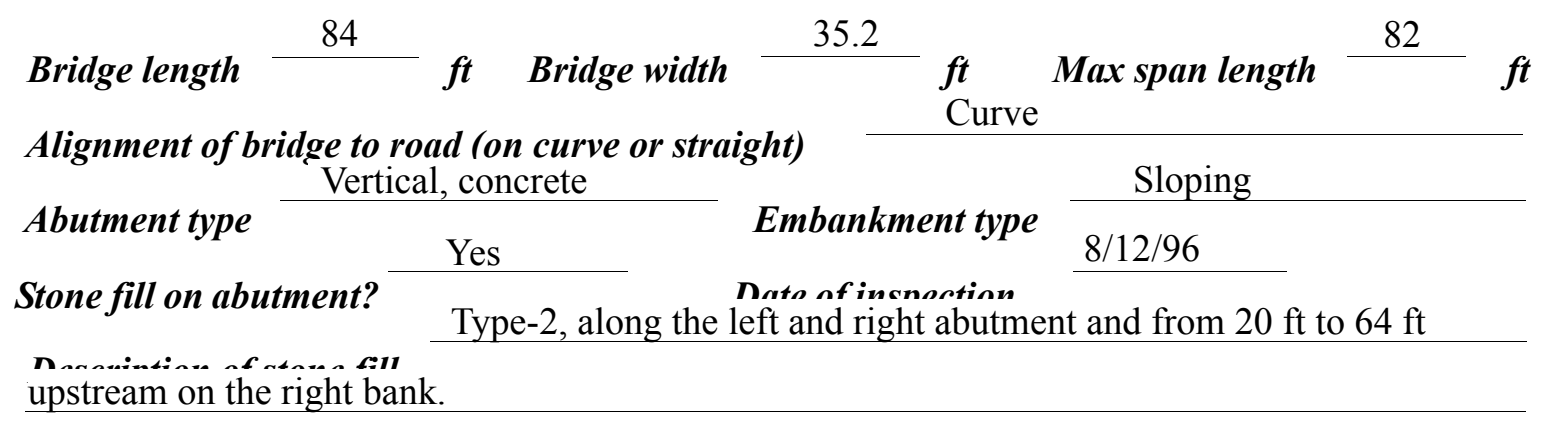

Abutments are concrete with spill-through

embankments. There is a half-foot deep scour hole at the toe of the right spill-through slope.

Yes

\section{5}

No

Is bridge skewed to flood flow according to There ' survey?

Angle

is a mild channel bend in the upstream reach.

Debris accumulation on bridge at time of Level I or Level II site visit:

\begin{tabular}{|c|c|c|c|}
\hline & $\begin{array}{c}\text { Date of insmortion } \\
8 / 12 / 96 \\
\end{array}$ & $\begin{array}{l}\text { Percent of alommol } \\
\text { blocked hortzontatly }\end{array}$ & $\begin{array}{l}\text { Percent of } 0 \\
\text { blocked verticatty }\end{array}$ \\
\hline & $8 / 12 / 96$ & 0 & 0 \\
\hline
\end{tabular}

Level II

High. There are trees leaning over the channel upstream and tree debris in the channel area near the bridge. Ice build up is evident from scarring on trees. There Potontial for dohris is a cut bank on the upstream right bank with exposed tree roots.

There was a mid-channel bar under the bridge extending into the downstream channel as of 8/12/96. Doscriho anv foaturos noar ar at tho hridos that mav affort flow, (includo ahsorvation dato) There was also tree debris in the channel which will affect flow at lower flows. 


\section{Description of the Geomorphic Setting}

General topography The channel is located within a moderate relief valley with steep valley walls on both sides near the confluence with the West River.

Geomorphic conditions at bridge site: downstream (DS), upstream (US)

Date of inspection $\quad 8 / 12 / 96$

DS left: $\quad$ Steep channel bank to a narrow terrace.

DS right: $\quad$ Steep channel bank to a moderately sloped overbank.

US left: $\quad$ Steep valley wall.

US right: $\quad$ Steep channel bank to a moderately sloped overbank.

\section{Description of the Channel}

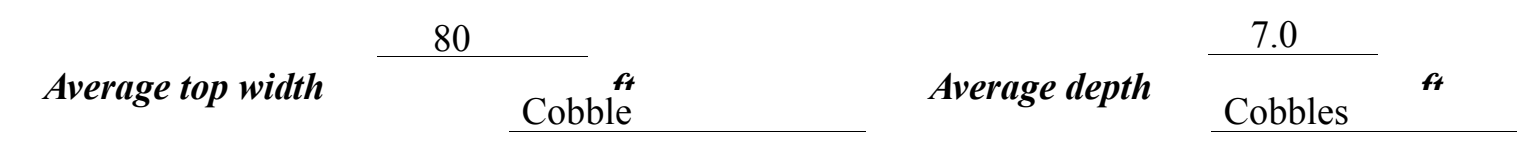

Predominant bed material

Bank material

Straight channel with

aggrading bed material, semi-alluvial channel boundaries and no flö plain.

$8 / 12 / 96$

Vegetative co 1 Trees and brush.

DS left: $\quad$ Trees and brush.

DS right: $\quad$ Trees and brush.

US left: $\quad$ Trees and brush.

US right: $\quad$ No

Do banks appear stable? Moderate to heavy fluvial erosion along both banks with a cut bank datong the upstream right bank.

The assessment of

$8 / 12 / 96$ noted a mid-channel bar under the bridge extending downstream. There was a tree in the Describe any obstructions in channel and date of observation.

channel under the bridge on $8 / 12 / 96$. 


\title{
Hydrology
}

Drainage area $\quad \frac{6.31}{m_{i}{ }^{2}}$

Percentage of drainage area in physiographic provinces: (approximate)

Physiographic province/section New England/New England Upland
Percent of drainage area 100

\begin{abstract}
Is drainage area considered rural or urban?
Rural urbanization:

Describe any significant
\end{abstract}



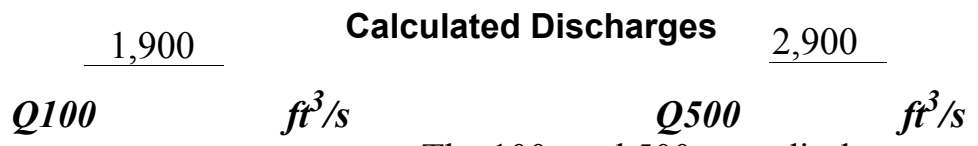

The 100- and 500-year discharges are based on a

drainage area relationship [(6.30/6.31)exp 0.7] with bridge number 39 in Dummerston. Bridge number 39 crosses the Stickney Brook upstream of this site and has flood frequency estimates available from the VTAOT database. The drainage area above bridge number 39 is 6.30 square miles. These values are within a range defined by several empirical flood frequency curves (Benson, 1962; Johnson and Tasker, 1974; FHWA, 1983; Potter, 1957a\&b; Talbot, 1887). 


\section{Description of the Water-Surface Profile Model (WSPRO) Analysis}

Datum for WSPRO analysis (USGS survey, sea level, VTAOT plans)

USGS survey

Datum tie between USGS survey and VTAOT plans

Subtract $1 \mathrm{ft}$ from the USGS

arbitrary survey datum to obtain VTAOT plans' datum.

Description of reference marks used to determine USGS datum. $\quad$ RM1 is a chiseled X on

top of the downstream end of the right abutment (elev. $500.53 \mathrm{ft}$, arbitrary survey datum). RM2

is the center of a chiseled square on top of the upstream end of the left abutment (elev. $501.17 \mathrm{ft}$,

arbitrary survey datum).

Cross-Sections Used in WSPRO Analysis

\begin{tabular}{|c|c|c|c|}
\hline${ }^{1}$ Cross-section & $\begin{array}{c}\text { Section } \\
\text { Reference } \\
\text { Distance } \\
\text { (SRD) in feet }\end{array}$ & $\begin{array}{c}{ }^{2} \text { Cross-section } \\
\text { development }\end{array}$ & Comments \\
\hline EXITX & -67 & 1 & Exit section \\
\hline FULLV & 0 & 2 & $\begin{array}{l}\text { Downstream Full-valley } \\
\text { section (Templated from } \\
\text { EXITX) }\end{array}$ \\
\hline BRIDG & 0 & 1 & Bridge section \\
\hline RDWAY & 19 & 1 & Road Grade section \\
\hline APPRO & 118 & 1 & Approach section \\
\hline
\end{tabular}

${ }^{1}$ For location of cross-sections see plan-view sketch included with Level I field form, Appendix E.

For more detail on how cross-sections were developed see WSPRO input file. 


\section{Data and Assumptions Used in WSPRO Model}

Hydraulic analyses of the reach were done by use of the Federal Highway Administration's WSPRO step-backwater computer program (Shearman and others, 1986, and Shearman, 1990). The analyses reported herein reflect conditions existing at the site at the time of the study. Furthermore, in the development of the model it was necessary to assume no accumulation of debris or ice at the site. Results of the hydraulic model are presented in the Bridge Hydraulic Summary, Appendix B, and figure 7.

Channel roughness factors (Manning's " $n$ ") used in the hydraulic model were estimated using field inspections at each cross section following the general guidelines described by Arcement and Schneider (1989). Final adjustments to the values were made during the modelling of the reach. Channel " $\mathrm{n}$ " values for the reach ranged from 0.050 to 0.060 , and overbank " $\mathrm{n}$ " values ranged from 0.065 to 0.080 .

Normal depth at the exit section (EXITX) was assumed as the starting water surface. This depth was computed by use of the slope-conveyance method outlined in the user's manual for WSPRO (Shearman, 1990). The slope used was $0.036 \mathrm{ft} / \mathrm{ft}$ which was calculated from the surveyed thalweg points downstream of the bridge. Stickney Brook enters the West River 180 feet downstream of the bridge forming a large deltaic deposit at low flows. Due to the steep downstream channel of Stickney Brook the effects of backwater from the West River were ignored.

The approach section (APPRO) was surveyed one bridge length upstream of the upstream face as recommended by Shearman and others (1986). This location provides a consistent method for determining scour variables.

For the 100-year and 500-year discharges, WSPRO assumes critical depth at the bridge section. Supercritical models were developed for these discharges. After analyzing both the supercritical and subcritical profiles for each discharge, it can be determined that the water surface profile does pass through critical depth within the bridge opening. Thus, the assumptions of critical depth at the bridge are satisfactory solutions. 


\section{Bridge Hydraulics Summary}

$\begin{array}{lll}\text { Average bridge embankment elevation } & 500.4 \\ \text { Average low steel elevation } & 496.0 & \boldsymbol{f t}\end{array}$

100-year discharge $\quad 1,900 \quad \mathrm{ft}^{3} / \mathrm{s}$

Water-surface elevation in bridge opening $\quad 488.0 \quad f t$

Road overtopping? ___ No Discharge over road ___-- $\mathrm{ft}^{3} / \mathrm{s}$

Area of flow in bridge opening $\quad 176 \quad \mathrm{ft}^{2}$

Average velocity in bridge opening $10.8 \mathrm{ft} / \mathrm{s}$

$\begin{array}{llll}\text { Maximum WSPRO tube velocity at bridge } & 12.7 & \mathrm{ft} / \mathrm{s}\end{array}$

Water-surface elevation at Approach section with bridge 492.3

Water-surface elevation at Approach section without bridge $\quad 491.9$

Amount of backwater caused by bridge $\quad 0.4$ it

500-year discharge $\quad 2,900 \quad \mathrm{ft}^{3} / \mathrm{s}$

Water-surface elevation in bridge opening $\quad 489.2 \mathrm{ft}$

Road overtopping? ___ No Discharge over road __ - - $\quad, t^{3} / s$

Area of flow in bridge opening $\quad 241 \quad \mathrm{ft}^{2}$

Average velocity in bridge opening $12.0 \mathrm{ft} / \mathrm{s}$

Maximum WSPRO tube velocity at bridge 13.9 's

Water-surface elevation at Approach section with bridge 493.4

Water-surface elevation at Approach section without bridge $\quad 493.3$

Amount of backwater caused by bridge $\quad 0.1, t$

Incipient overtopping discharge ___ -- $f^{3} / \mathrm{s}$

Water-surface elevation in bridge opening $\quad--\quad t$

Area of flow in bridge opening _ $\quad--\quad \mathrm{ft}^{2}$

Average velocity in bridge opening $\quad--\quad f t / s$

Maximum WSPRO tube velocity at bridge _-- $\mathrm{ft} / \mathrm{s}$

Water-surface elevation at Approach section with bridge

Water-surface elevation at Approach section without bridge

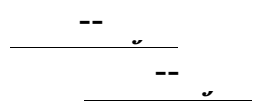

Amount of backwater caused by bridge _ 


\section{Scour Analysis Summary}

\section{Special Conditions or Assumptions Made in Scour Analysis}

Scour depths were computed using the general guidelines described in Hydraulic Engineering Circular 18 (Richardson and others, 1995). Scour depths were calculated assuming an infinite depth of erosive material and a homogeneous particle-size distribution. The results of the scour analysis are presented in tables 1 and 2 and a graph of the scour depths is presented in figure 8.

Contraction scour was computed by use of the live-bed contraction scour equation (Richardson and others, 1995, p. 30, equation 17). Results of this analysis are presented in figure 8 and tables 1 and 2 . The streambed armoring depths computed suggest that armoring will not limit the depth of contraction scour.

Abutment scour was computed by use of the Froehlich equation (Richardson and others, 1995, p. 48, equation 28). Variables for the Froehlich equation include the Froude number of the flow approaching the embankments, the length of the embankment blocking flow, and the depth of flow approaching the embankment less any roadway overtopping.

Because the influence of scour processes on the spill-through embankment material is uncertain, the scour depth at the vertical concrete abutment walls is unknown. Therefore, the total scour depths were applied for the entire spill-through embankment below the elevation at the toe of each embankment and extended to the vertical concrete abutment wall, as shown in figure 8 . 


\section{Scour Results}

\section{0-yr discharge 500-yr discharge}

Contraction scour:

(Scour depths in feet)

Main channel

Live-bed scour

Clear-water scour

Depth to armoring

Left overbank

Right overbank

Local scour:

Abutment scour

Left abutment

5.5

2.0 .

6.3

3.8

Right abutment

Pier scour

Pier 1

Pier 2

Pier 3

\section{Abutments:}

\section{Left abutment}

\section{Right abutment}

Piers:

Pier 1

Pier 2

Incipient overtopping discharge 


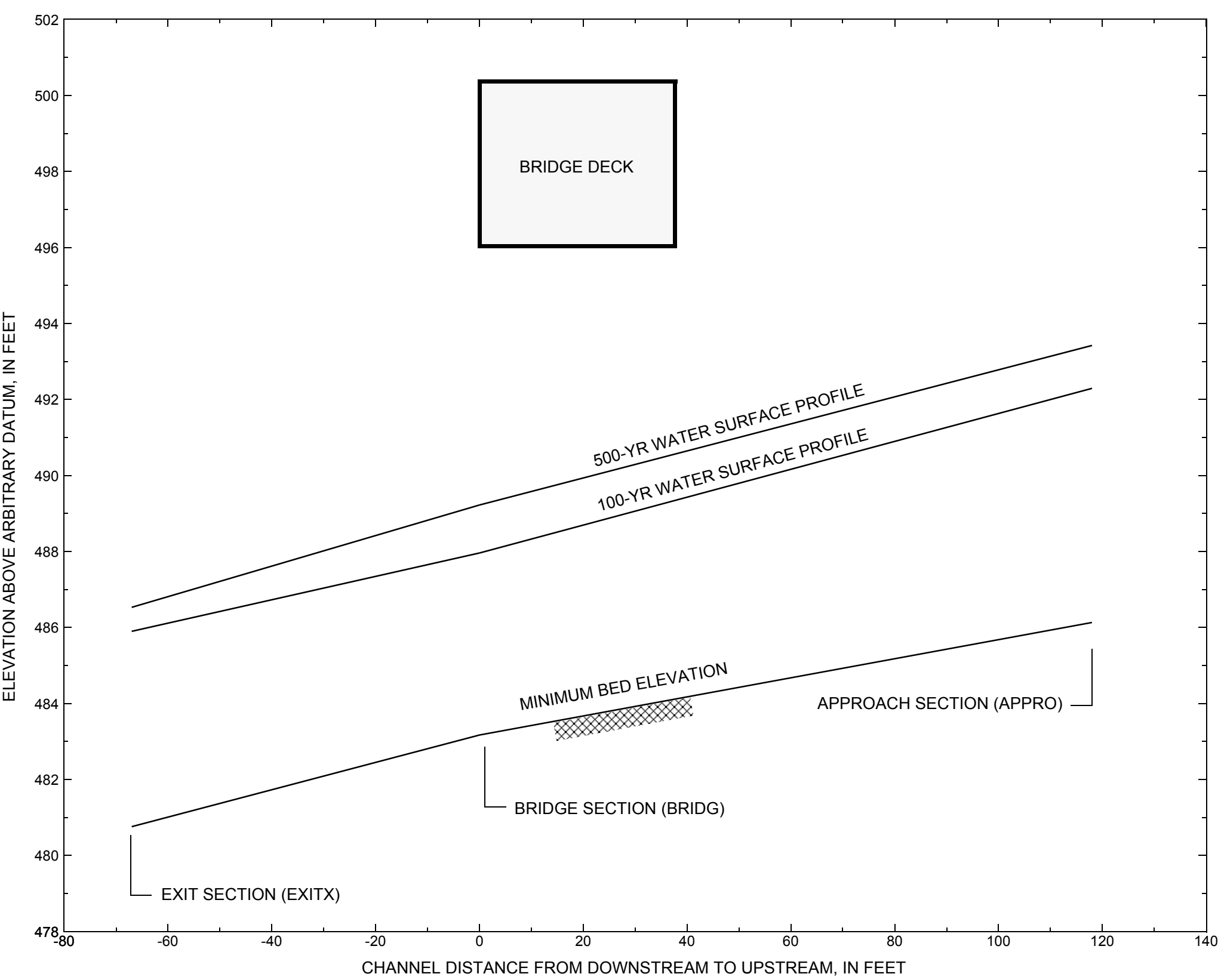

Figure 7. Water-surface profiles for the 100- and 500-yr discharges at structure DUMMVT00300005 on State Route 30, crossing Stickney Brook, Dummerston, Vermont. 


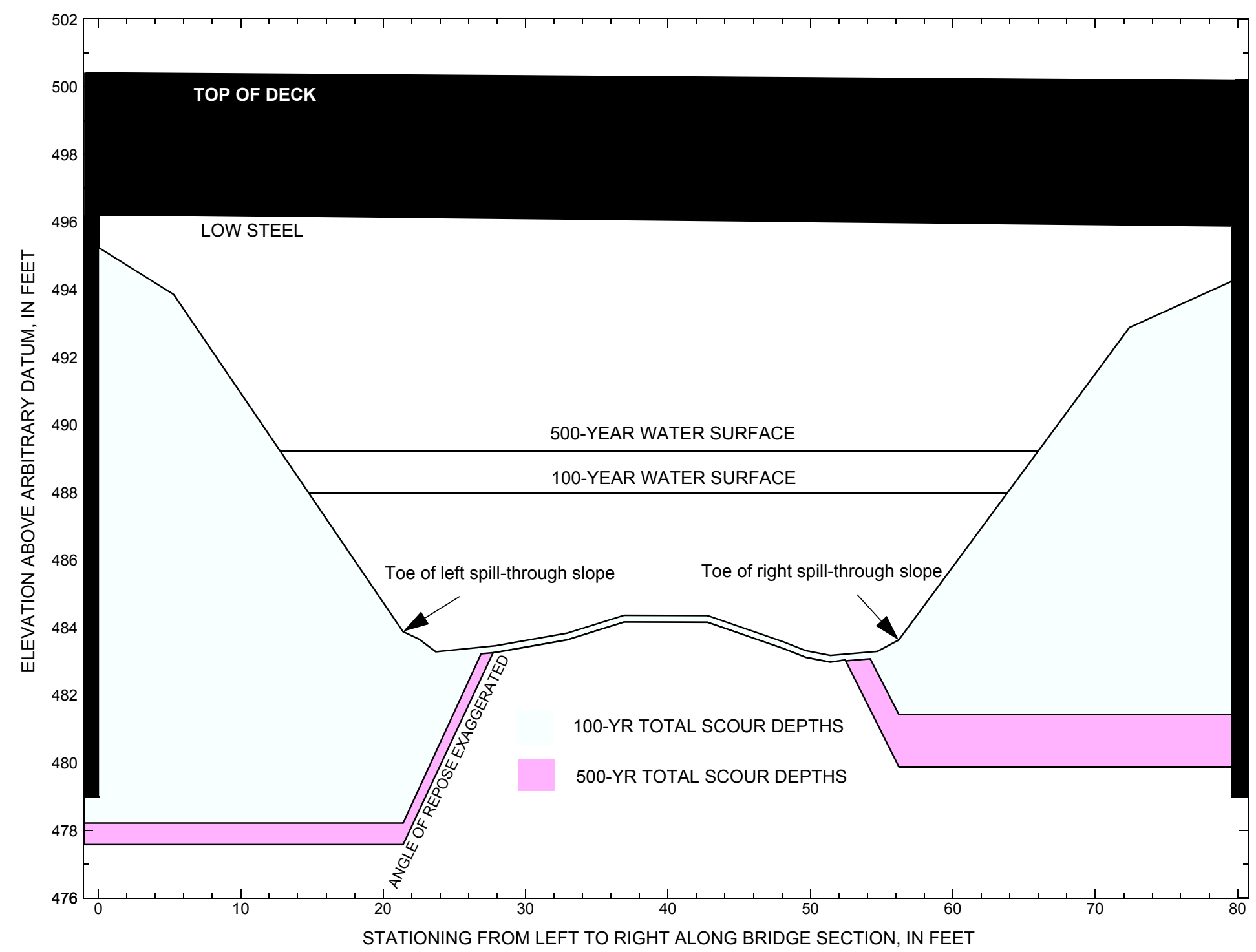

Figure 8. Scour elevations for the 100-yr and 500-yr discharges at structure DUMMVT00300005 on State Route 30, crossing Stickney Brook, Dummerston, Vermont. 
Table 1. Remaining footing/pile depth at abutments for the 100-year discharge at structure DUMMVT00300005 on State Route 30, crossing Stickney Brook, Dummerston, Vermont.

[VTAOT, Vermont Agency of Transportation; --,no data]

\begin{tabular}{|c|c|c|c|c|c|c|c|c|c|c|c|}
\hline Description & Station ${ }^{1}$ & $\begin{array}{l}\text { VTAOT } \\
\text { minimum } \\
\text { bridge seat } \\
\text { elevation } \\
\text { (feet) }\end{array}$ & $\begin{array}{l}\text { Surveyed } \\
\text { minimum } \\
\text { low-chord } \\
\text { elevation }{ }^{2} \\
\text { (feet) }\end{array}$ & $\begin{array}{l}\text { Bottom of } \\
\text { footing } \\
\text { elevation } \\
\text { (feet) }\end{array}$ & $\begin{array}{c}\text { Channel } \\
\text { elevation at } \\
\text { abutment/ } \\
\text { pier }^{2} \\
\text { (feet) }\end{array}$ & $\begin{array}{l}\text { Contraction } \\
\text { scour depth } \\
\text { (feet) }\end{array}$ & $\begin{array}{l}\text { Abutment } \\
\text { scour } \\
\text { depth } \\
\text { (feet) }\end{array}$ & $\begin{array}{l}\text { Pier } \\
\text { scour } \\
\text { depth } \\
\text { (feet) }\end{array}$ & $\begin{array}{l}\text { Depth of } \\
\text { total scour } \\
\text { (feet) }\end{array}$ & $\begin{array}{c}\text { Elevation of } \\
\text { scour }^{2} \\
\text { (feet) }\end{array}$ & $\begin{array}{c}\text { Remaining } \\
\text { footing/pile } \\
\text { depth } \\
\text { (feet) }\end{array}$ \\
\hline
\end{tabular}

\begin{tabular}{|c|c|c|c|c|c|c|c|c|c|c|c|}
\hline Left abutment & 0.0 & -- & 496.2 & 479.0 & -- & -- & -- & -- & -- & -- & -0.8 \\
\hline $\begin{array}{c}\text { Toe of left } \\
\text { spill-through slope }\end{array}$ & 21.4 & -- & -- & -- & 483.9 & 0.2 & 5.5 & -- & 5.7 & 478.2 & -- \\
\hline $\begin{array}{l}\text { Toe of right } \\
\text { spill-through slope }\end{array}$ & 56.2 & -- & -- & -- & 483.6 & 0.2 & 2.0 & -- & 2.2 & 481.4 & -- \\
\hline Right abutment & 79.7 & -- & 495.9 & 479.0 & -- & -- & -- & -- & -- & -- & 2.4 \\
\hline
\end{tabular}

1.Measured along the face of the most constricting side of the bridge.

2.Arbitrary datum for this study.

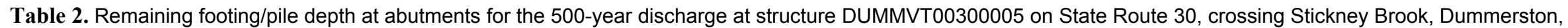
Vermont.

[VTAOT, Vermont Agency of Transportation; --, no data]

\begin{tabular}{|c|c|c|c|c|c|c|c|c|c|c|c|}
\hline Description & Station $^{1}$ & $\begin{array}{l}\text { VTAOT } \\
\text { minimum } \\
\text { bridge seat } \\
\text { elevation } \\
\text { (feet) }\end{array}$ & $\begin{array}{l}\text { Surveyed } \\
\text { minimum } \\
\text { low-chord } \\
\text { elevation }{ }^{2} \\
\text { (feet) }\end{array}$ & $\begin{array}{l}\text { Bottom of } \\
\text { footing } \\
\text { elevation } \\
\text { (feet) }\end{array}$ & $\begin{array}{c}\text { Channel } \\
\text { elevation at } \\
\text { abutment/ } \\
\text { pier }^{2} \\
\text { (feet) }\end{array}$ & $\begin{array}{l}\text { Contraction } \\
\text { scour depth } \\
\text { (feet) }\end{array}$ & $\begin{array}{l}\text { Abutment } \\
\text { scour } \\
\text { depth } \\
\text { (feet) }\end{array}$ & $\begin{array}{l}\text { Pier scour } \\
\text { depth } \\
\text { (feet) }\end{array}$ & $\begin{array}{l}\text { Depth of } \\
\text { total scour } \\
\text { (feet) }\end{array}$ & $\begin{array}{c}\text { Elevation of } \\
\text { scour }^{2} \\
\text { (feet) }\end{array}$ & $\begin{array}{c}\text { Remaining } \\
\text { footing/pile } \\
\text { depth } \\
\text { (feet) }\end{array}$ \\
\hline \multicolumn{12}{|c|}{500 -yr. discharge is 2,900 cubic-feet per second } \\
\hline Left abutment & 0.0 & -- & 496.2 & 479.0 & -- & -- & -- & -- & -- & -- & -1.4 \\
\hline $\begin{array}{c}\text { Toe of left } \\
\text { spill-through slope }\end{array}$ & 21.4 & -- & -- & -- & 483.9 & 0.0 & 6.3 & -- & 6.3 & 477.6 & -- \\
\hline $\begin{array}{c}\text { Toe of right } \\
\text { spill-through slope }\end{array}$ & 56.2 & -- & -- & -- & 483.6 & 0.0 & 3.8 & -- & 3.8 & 479.8 & -- \\
\hline Right abutment & 79.7 & -- & 495.9 & 479.0 & -- & -- & -- & -- & -- & -- & 0.8 \\
\hline
\end{tabular}

1.Measured along the face of the most constricting side of the bridge.

2.Arbitrary datum for this study. 


\section{SELECTED REFERENCES}

Arcement, G.J., Jr., and Schneider, V.R., 1989, Guide for selecting Manning's roughness coefficients for natural channels and flood plains: U.S. Geological Survey Water-Supply Paper 2339, 38 p.

Barnes, H.H., Jr., 1967, Roughness characteristics of natural channels: U.S. Geological Survey Water-Supply Paper 1849,213 p.

Benson, M. A., 1962, Factors Influencing the Occurrence of Floods in a Humid Region of Diverse Terrain: U.S. Geological Survey WaterSupply Paper 1580-B, 64 p.

Brown, S.A. and Clyde, E.S., 1989, Design of riprap revetment: Federal Highway Administration Hydraulic Engineering Circular No. 11, Publication FHWA-IP-89-016, 156 p.

Federal Highway Administration, 1983, Runoff estimates for small watersheds and development of sound design: Federal Highway Administration Report FHWA-RD-77-158.

Federal Highway Administration, 1993, Stream Stability and Scour at Highway Bridges: Participant Workbook: Federal Highway Administration Report FHWA-HI-91-011.

Froehlich, D.C., 1989, Local scour at bridge abutments in Ports, M.A., ed., Hydraulic Engineering--Proceedings of the 1989 National Conference on Hydraulic Engineering: New York, American Society of Civil Engineers, p. 13-18.

Hayes, D.C.,1993, Site selection and collection of bridge-scour data in Delaware, Maryland, and Virginia: U.S. Geological Survey WaterResources Investigation Report 93-4017, 23 p.

Interagency Advisory Committee on Water Data, 1982, Guidelines for determining flood flow frequency: U.S. Geological Survey, Bulletin 17B of the Hydrology Subcommittee, 190 p.

Johnson, C.G. and Tasker, G.D.,1974, Progress report on flood magnitude and frequency of Vermont streams: U.S. Geological Survey OpenFile Report 74-130, 37 p.

Lagasse, P.F., Schall, J.D., Johnson, F., Richardson, E.V., Chang, F., 1995, Stream Stability at Highway Structures: Federal Highway Administration Hydraulic Engineering Circular No. 20, Publication FHWA-IP-90-014, 144 p.

Laursen, E.M., 1960, Scour at bridge crossings: Journal of the Hydraulics Division, American Society of Civil Engineers, v. 86, no. HY2, p. 39-53.

Potter, W. D., 1957a, Peak rates of runoff in the Adirondack, White Mountains, and Maine woods area, Bureau of Public Roads

Potter, W. D., 1957b, Peak rates of runoff in the New England Hill and Lowland area, Bureau of Public Roads

Richardson, E.V. and Davis, S.R., 1995, Evaluating scour at bridges: Federal Highway Administration Hydraulic Engineering Circular No. 18, Publication FHWA-IP-90-017, 204 p.

Richardson, E.V., Simons, D.B., and Julien, P.Y., 1990, Highways in the river environment: Federal Highway Administration Publication FHWA-HI-90-016.

Ritter, D.F., 1984, Process Geomorphology: W.C. Brown Co., Debuque, Iowa, 603 p.

Shearman, J.O., 1990, User's manual for WSPRO--a computer model for water surface profile computations: Federal Highway Administration Publication FHWA-IP-89-027, 187 p.

Shearman, J.O., Kirby, W.H., Schneider, V.R., and Flippo, H.N., 1986, Bridge waterways analysis model; research report: Federal Highway Administration Publication FHWA-RD-86-108, 112 p.

Talbot, A.N., 1887, The determination of water-way for bridges and culverts.

U.S. Department of Transportation, 1993, Stream stability and scour at highway bridges, Participant Workbook: Federal Highway Administration Publication FHWA HI-91-011.

U.S. Geological Survey, 1984, Newfane, Vermont 7.5 X 15 Minute Series quadrangle map: U.S. Geological Survey Topographic Maps, Scale 1:25,000. 


\section{APPENDIX A: \\ WSPRO INPUT FILE}




\section{WSPRO INPUT FILE}

XS

GR

GR

GR

GR

GR

GR

GR

$\mathrm{N}$

SA

*

X

*

BR

GR

GR

GR

GR

GR

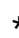

$\mathrm{CD}$

$\mathrm{N}$

*

*

$\mathrm{XR}$

GR

GR

GR

GR

*

AS

GR

GR

GR

GR

GR

$\mathrm{N}$

SA

HP 1 BRIDG

HP 2 BRIDG

HP 1 APPRO

HP 2 APPRO

*

HP 1 BRIDG

HP 2 BRIDG
U.S. Geological Survey WSPRO Input File dumm005.wsp Hydraulic analysis for structure DUMMVT00300005 Date: 05-FEB-97 Bridge \# 5 on VT 30 over stickney Brook in Dummerston, VT by MAI

$62930 \quad 552553551516 \quad 17 \quad 13 \quad 3 * \begin{array}{llllllllll}15 & 14 & 23 & 21 & 11 & 12 & 4 & 7 & 3\end{array}$
$\operatorname{EXITX} \quad-67$

$-258.5,514.72$

$-66.2,499.82-27.3,485.87$

$20.9,482.17 \quad 23.0,481.82$

$34.5,482.43 \quad 38.0,481.50$

$42.7,480.76$

$93.2,490.47$

$46.0,481.20$

$123.8,490.81$

$260.5,500.01 \quad 302.2,499.67$

0.075

$-27.3$

0.075

93.2

0.0360

SRD LSEL XSSKEW

$\begin{array}{lll}0 & 496.04 & 0.0\end{array}$

$0.0,496.21 \quad 0.1,495.25$

$22.5,483.66$

$36.9,484.36$

$51.4,483.17$

$79.6,494.25$

$23.7,483.28$

$42.8,484.35$

$54.7,483.29$

$79.7,495.86$

$-190.8,501.61$

$0.0,484.24$

$30.6,481.87$

$39.6,481.25$

$55.2,484.19$

$162.9,491.92$

$375.9,504.84$

$5.3,493.85$

$27.9,483.46$

$48.1,483.58$

$56.2,483.63$

$0.0,496.21$
0.060
$-110.1,500.89$

$15.6,483.84$

$31.3,482.00$

$40.5,480.94$

$84.3,484.89$

$184.2,498.63$
$21.4,483.88$

$32.9,483.83$

$49.7,483.31$

$72.4,492.88$ $\begin{array}{rrrr} & \text { SRD } & \text { EMBWID } & \text { IPAVE } \\ \text { RDWAY } & 19 & 35.2 & 1\end{array}$

$-232.2,514.72-206.7,502.1$

$-9.7,500.56 \quad-9.7,501.41$

$73.2,501.16 \quad 75.2,501.14$

$236.1,500.01$

$271.5,499.67$
$-100.7,504.10$

$20.4,486.25$

$34.4,486.60$

$116.5,495.23$

$52.4,493.15$

$174.4,513.38$

0.065

$$
11.2
$$

0.060

52.4
$-152.6,501.61$

$-6.7,501.39$

$75.4,500.18$

$340.8,504.84$

$$
\begin{array}{rr}
0.0, & 502.13 \\
26.4, & 486.13 \\
37.9, & 486.23 \\
130.6, & 501.19
\end{array}
$$

$-72.0,500.89$

$0.0,501.39$

$116.4,499.95$

$\begin{array}{rr}11.2, & 492.83 \\ 28.3, & 486.67 \\ 41.0, & 486.71 \\ 161.8, & 502.45\end{array}$

487.961487 .96

487.96 * * 1900

492.291492 .29

$492.29 *$ * 1900

489.221489 .22

489.22 * 22900 


\section{APPENDIX B: \\ WSPRO OUTPUT FILE}


U.S. Geological Survey WSPRO Input File dumm005.wsp

Hydraulic analysis for structure DUMMVT00300005 Date: 05-FEB-97 Bridge \# 5 on VT 30 over Stickney Brook in Dummerston, VT by MAI *** RUN DATE \& TIME: 02-27-97 14:27

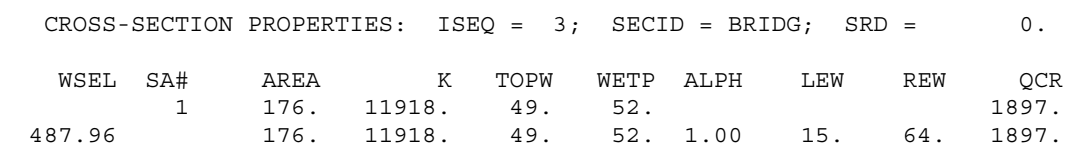

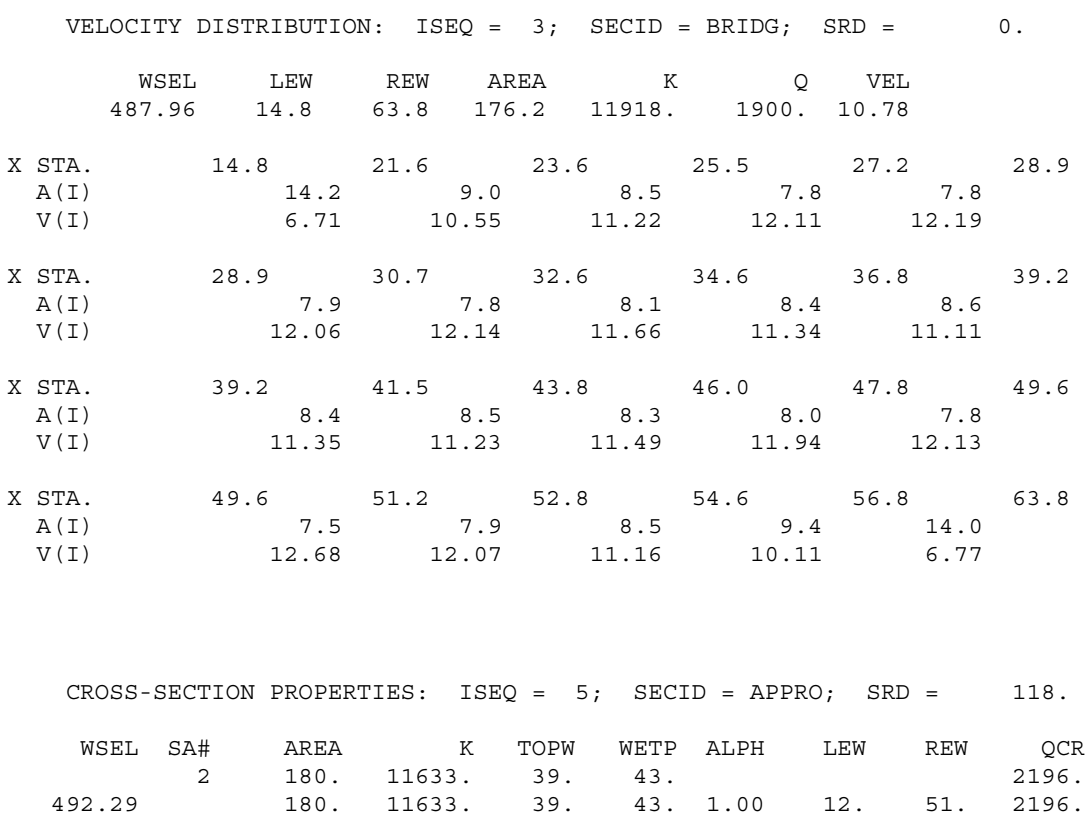

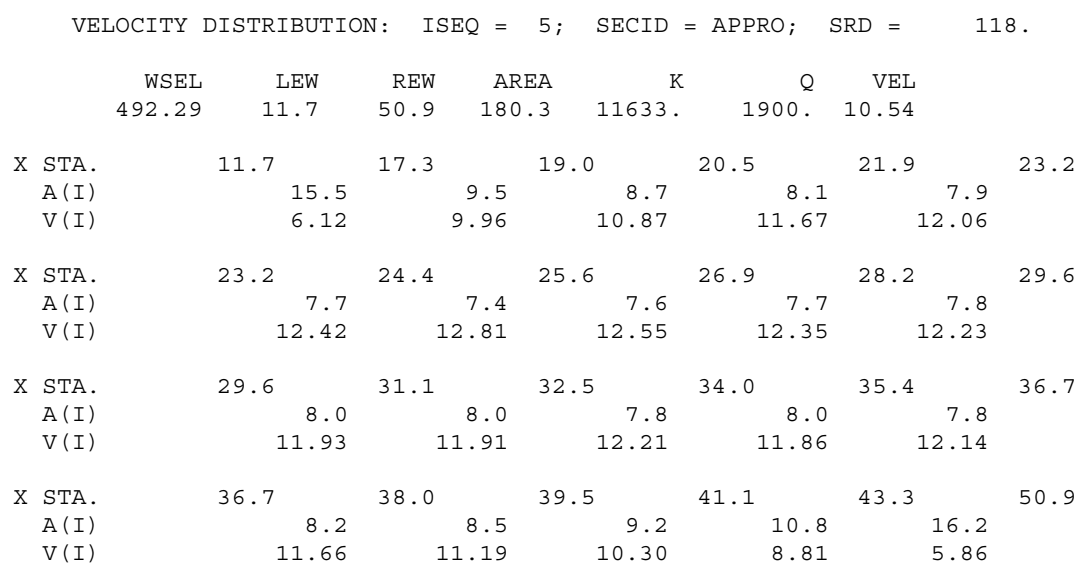


U.S. Geological Survey WSPRO Input File dumm005.wsp

Hydraulic analysis for structure DUMMVT00300005 Date: 05-FEB-97 Bridge \# 5 on VT 30 over stickney Brook in Dummerston, VT by MAI *** RUN DATE \& TIME: 02-27-97 14:27

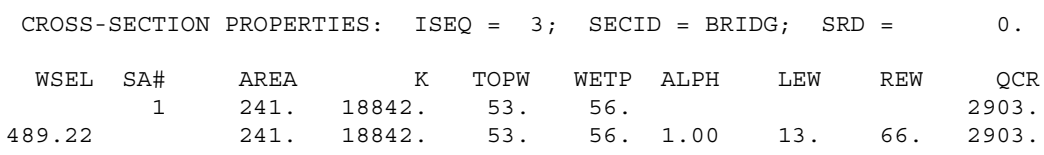

\begin{tabular}{|c|c|c|c|c|c|c|c|c|c|c|c|}
\hline & VELOC & TY DISTF & RIBUTIO & ISE & $Q=$ & $3 ;$ & SECID = & BRIDG ; & $\mathrm{SRD}=$ & & 0 . \\
\hline & 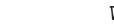 & ISEL & LEW & REW & ARI & EA & K & $Q$ & VEL & & \\
\hline & 48 & .22 & 12.8 & 66.0 & 240 & .6 & 18842. & 2900. & 12.05 & & \\
\hline $\mathrm{x}$ & STA. & 12.8 & & 20.8 & & 23.2 & & 25.1 & 27.0 & & 28.8 \\
\hline & $A(I)$ & & 20.0 & & 2.9 & & 11.4 & 10.9 & & 10.7 & \\
\hline & $V(I)$ & & 7.24 & 11 & .26 & & 12.70 & 13.31 & & 13.58 & \\
\hline $\mathrm{x}$ & STA. & 28.8 & & 30.7 & & 32.7 & & 34.7 & 36.9 & & 39.2 \\
\hline & $A(I)$ & & 10.7 & & 0.5 & & 10.8 & 11.1 & & 11.1 & \\
\hline & $V(I)$ & & 13.60 & 13 & .85 & & 13.45 & 13.12 & & 13.10 & \\
\hline $\mathrm{x}$ & STA. & 39.2 & & 41.5 & & 43.8 & & 45.9 & 47.8 & & 49.6 \\
\hline & $A(I)$ & & 11.2 & & 1.2 & & 10.8 & 10.7 & & 10.6 & \\
\hline & $V(I)$ & & 12.99 & 12 & .90 & & 13.47 & 13.59 & & 13.71 & \\
\hline $\mathrm{x}$ & STA. & 49.6 & & 51.4 & & 53.2 & & 55.2 & 57.6 & & 66.0 \\
\hline & $A(I)$ & & 10.6 & & 0.9 & & 11.5 & 13.2 & & 20.0 & \\
\hline & $\mathrm{V}(\mathrm{I})$ & & 13.71 & 13. & .31 & & 12.61 & 10.95 & & 7.23 & \\
\hline & CROSS & SECTION & PROPER & TIES: & ISEQ & 5 ; & SECID & $D=A P P R O$ & SRD & $=$ & 118. \\
\hline & WSEL & SA\# & AREA & I & K & TOPW & WETP & ALPH & LEW & REW & $\mathrm{QCR}$ \\
\hline & & 1 & 0. & 2. & & 1. & 1. & & & & 1. \\
\hline & & 2 & 226 . & 16329 & & 41. & 46. & & & & 3005 . \\
\hline & & 3 & 1. & 6. & & 8. & 8. & & & & 2. \\
\hline & 493.42 & & 227 . & 16336 & & 50. & 55. & 1.01 & 10. & 61. & 2731. \\
\hline
\end{tabular}

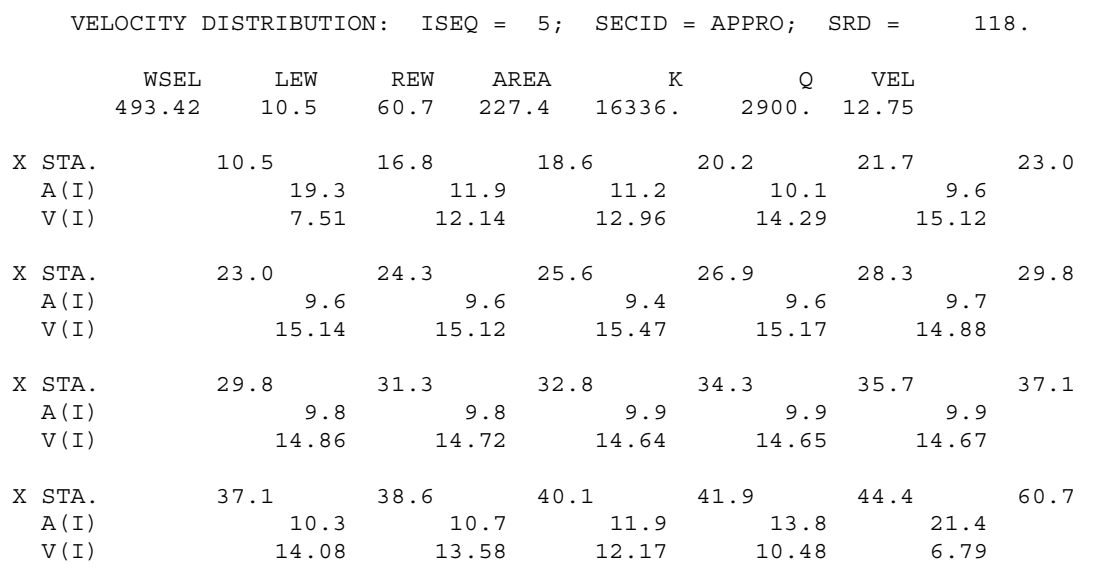


WSPRO OUTPUT FILE (continued)

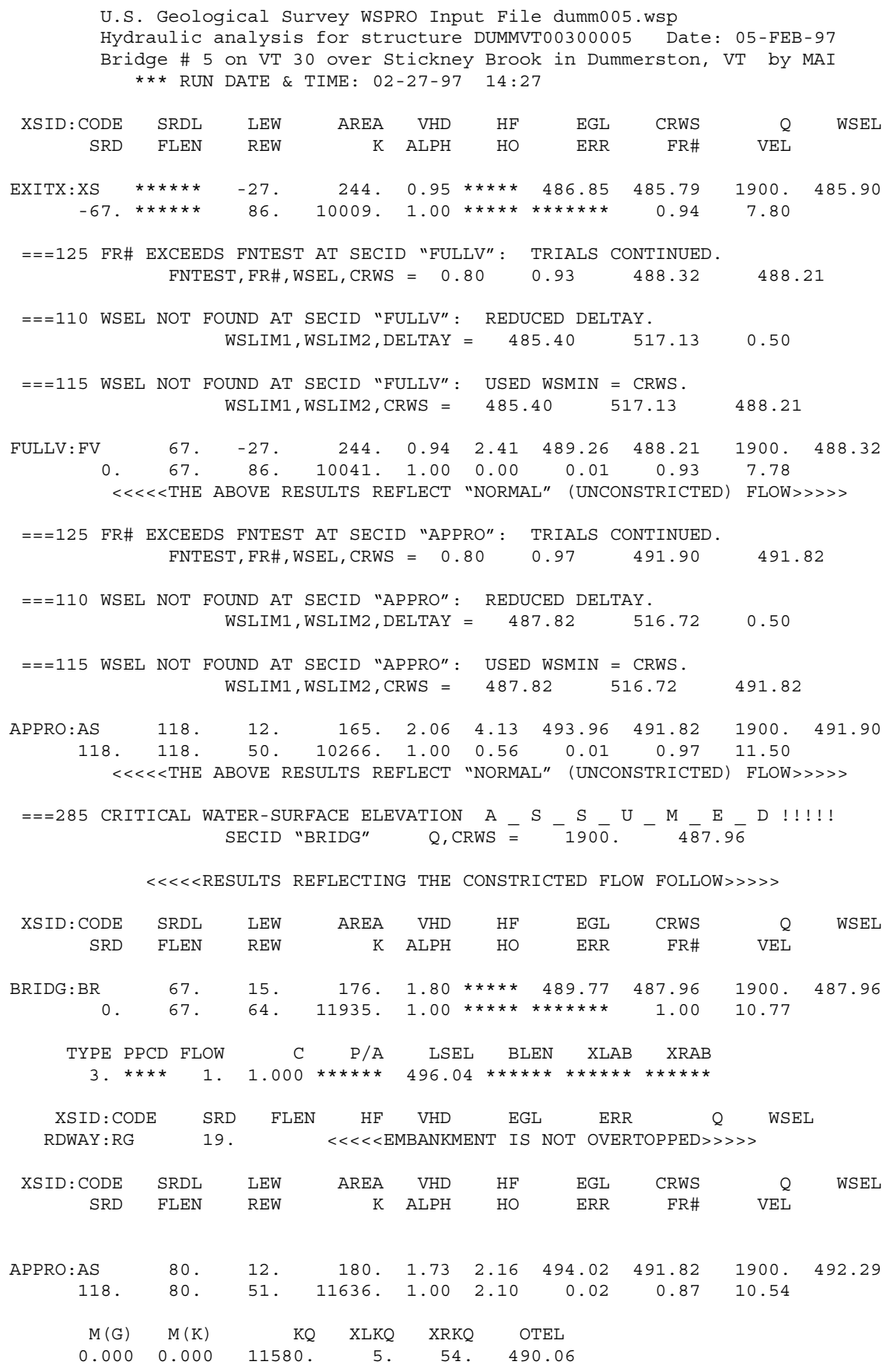

FIRST USER DEFINED TABLE.

\begin{tabular}{|c|c|c|c|c|c|c|c|c|}
\hline XSID : CODE & SRD & LEW & REW & Q & K & AREA & VEL & WSEL \\
\hline EXITX:XS & -67 & -27 & 86. & 1900 . & 10009 . & 244 . & 7.80 & 485.90 \\
\hline FULLV : FV & 0 & -27 & 86. & 1900. & 10041. & 244 & 7.78 & 488.32 \\
\hline BRIDG : BR & 0 . & 15. & 64. & 1900. & 11935. & 176 & 10.77 & 487.96 \\
\hline RDWAY : RG & \multicolumn{3}{|c|}{$19 . * * * * * * * * * * * * * *$} & \multicolumn{3}{|c|}{$0 . * * * * * * * * * * * * * * * * * * *$} & \multicolumn{2}{|c|}{$1.00 * * * * * * * *$} \\
\hline APPRO : AS & 118 & 12. & 51. & 1900. & 11636 & 180 & 10.54 & 492.29 \\
\hline XSID : CODE & XLKQ & XRKQ & & & & & & \\
\hline APPRO : AS & 5 . & 54. & 1158 & & & & & \\
\hline
\end{tabular}

SECOND USER DEFINED TABLE.

$\begin{array}{lcrrrrrrrr}\text { XSID : CODE } & \text { CRWS } & \text { FR\# } & \text { YMIN } & \text { YMAX } & \text { HF } & \text { HO } & \text { VHD } & \text { EGL } & \text { WSEL } \\ \text { EXITX:XS } & 485.79 & 0.94 & 480.76 & 514.72 * * * * * * * * * * & 0.95 & 486.85 & 485.90 \\ \text { FULLV:FV } & 488.21 & 0.93 & 483.17 & 517.13 & 2.41 & 0.00 & 0.94 & 489.26 & 488.32 \\ \text { BRIDG : BR } & 487.96 & 1.00 & 483.17 & 496.21 * * * * * * * * * * & 1.80 & 489.77 & 487.96 \\ \text { RDWAY:RG } & * * * * * * * * * * * * * * * & 499.67 & 514.72 * * * * * * * * * * * * * * * * * * * * * * * * * * * * * * * \\ \text { APPRO:AS } & 491.82 & 0.87 & 486.13 & 516.72 & 2.16 & 2.10 & 1.73 & 494.02 & 492.29\end{array}$


WSPRO OUTPUT FILE (continued)

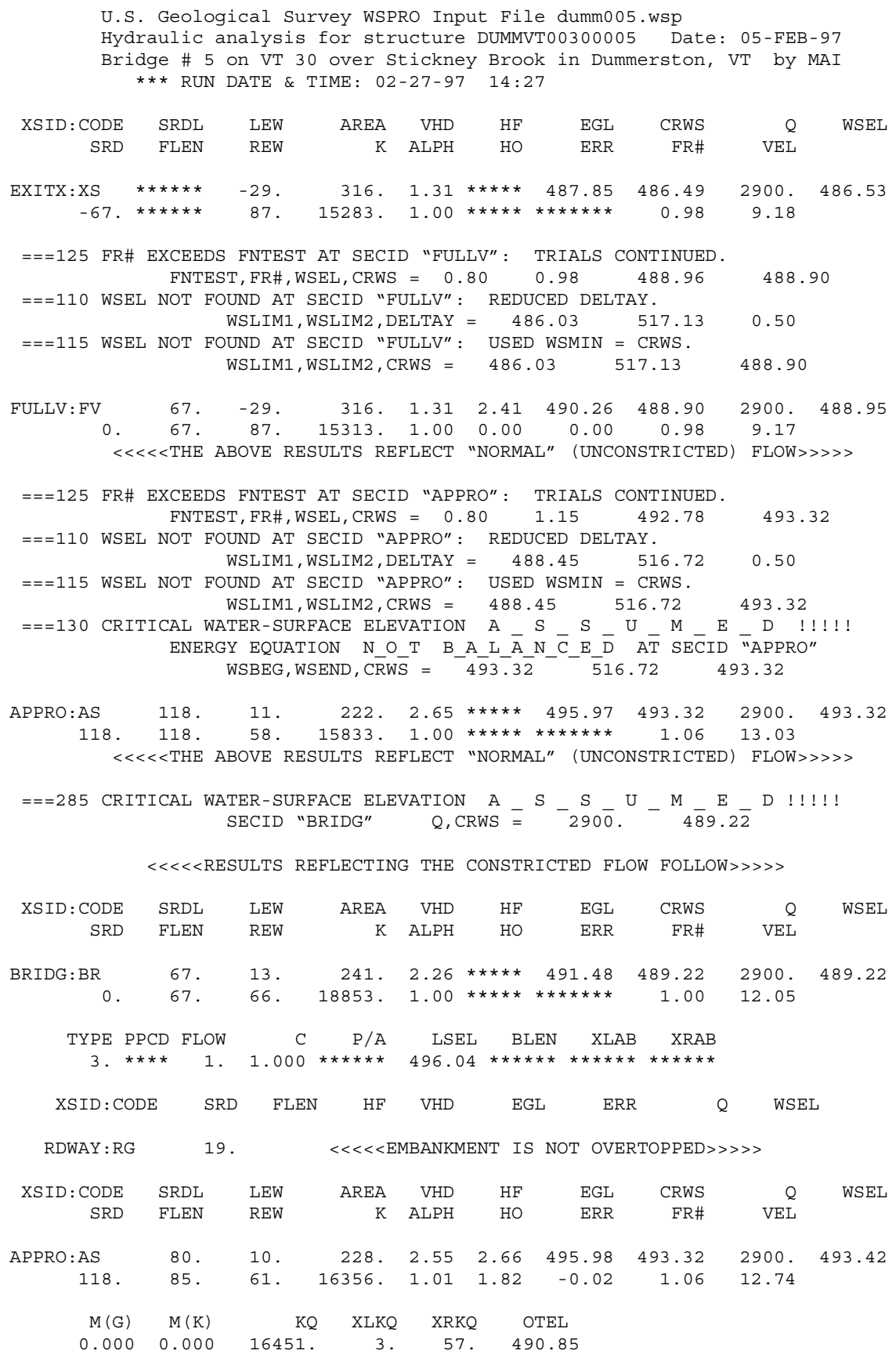

FIRST USER DEFINED TABLE.

\begin{tabular}{|c|c|c|c|c|c|c|c|c|}
\hline XSID : CODE & SRD & LEW & REW & $Q$ & K & AREA & VEL & WSEL \\
\hline EXITX:XS & -67 & -29 & 87. & 2900 . & 15283 & 316. & 9.18 & 486.53 \\
\hline FULLV : FV & 0 . & -29 & 87. & 2900 . & 15313. & 316. & 9.17 & 488.95 \\
\hline BRIDG : BR & 0 . & 13. & 66. & 2900 . & 18853 . & 241. & 12.05 & 489.22 \\
\hline RDWAY : RG & \multicolumn{3}{|c|}{ 19. $* * \star * \star * * * * * * * * *$} & \multicolumn{3}{|c|}{ 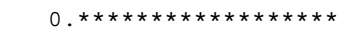 } & \multicolumn{2}{|c|}{$1.00 * * * * * * * *$} \\
\hline APPRO : AS & 118 & 10. & 61. & 2900. & 16356. & 228 & 12.74 & 493.42 \\
\hline XSID : CODE & XLKQ & XRKQ & & & & & & \\
\hline APPRO : AS & 3. & 57. & 1645 & & & & & \\
\hline
\end{tabular}

SECOND USER DEFINED TABLE.

$\begin{array}{lrrrrrrrrr}\text { XSID : CODE } & \text { CRWS } & \text { FR\# } & \text { YMIN } & \text { YMAX } & \text { HF } & \text { HO } & \text { VHD } & \text { EGL } & \text { WSEL } \\ \text { EXITX:XS } & 486.49 & 0.98 & 480.76 & 514.72 * * * * * * * * * * & 1.31 & 487.85 & 486.53 \\ \text { FULLV : FV } & 488.90 & 0.98 & 483.17 & 517.13 & 2.41 & 0.00 & 1.31 & 490.26 & 488.95 \\ \text { BRIDG : BR } & 489.22 & 1.00 & 483.17 & 496.21 * * * * * * * * * * & 2.26 & 491.48 & 489.22 \\ \text { RDWAY : RG } & * * * * * * * * * * * * * * * & 499.67 & 514.72 * * * * * * * * * * * * * * * * * * * * * * * * * * * * * * * \\ \text { APPRO:AS } & 493.32 & 1.06 & 486.13 & 516.72 & 2.66 & 1.82 & 2.55 & 495.98 & 493.42\end{array}$




\section{APPENDIX C:}

\section{BED-MATERIAL PARTICLE-SIZE DISTRIBUTION}




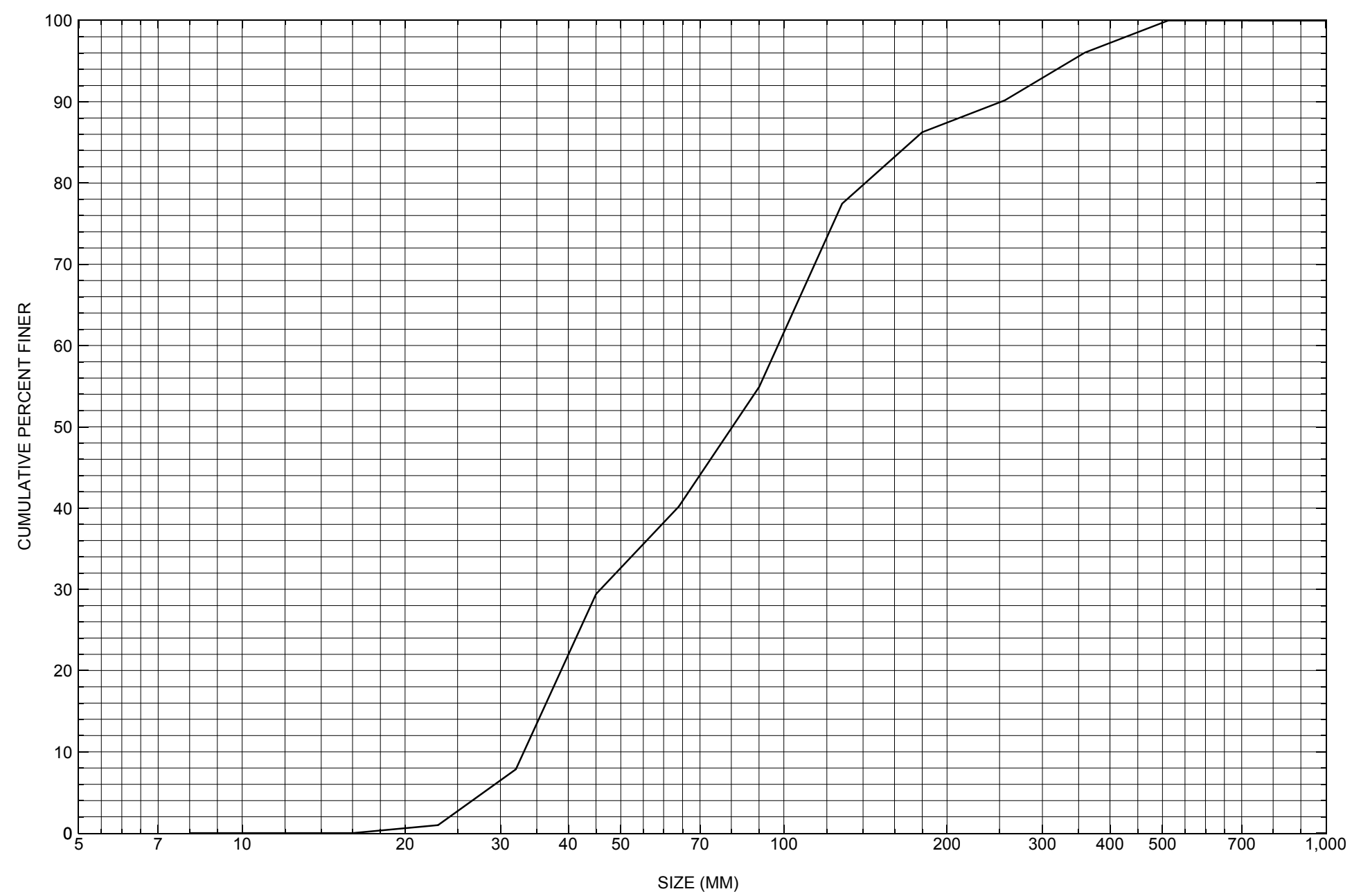

Appendix C. Bed material particle-size distribution for a pebble count in the channel approach of structure DUMMVT00300005, in Dummerston, Vermont. 


\section{APPENDIX D: \\ HISTORICAL DATA FORM}




\section{Structure Number DUMMVT00300005}

\section{General Location Descriptive}

Data collected by (First Initial, Full last name) $\mathbf{M}$. IVANOFF

Date $(M M / D D / Y Y) \_\mathbf{0 3} / \underline{\mathbf{3 0} /} \mathbf{9 5}$

Highway District Number (I - 2; nn) $\mathbf{0 2}$

Town (FIPS place code; I - 4; nnnnn) 18325

Waterway (I - 6) STICKNEY BROOK

Route Number VT 30

Topographic Map Newfane

Latitude (I - 16; nnnn.n) $\mathbf{4 2 5 5 1}$
County (FIPS county code; I - 3; nnn)

Mile marker (I - 11; nnn.nnn) $\mathbf{0 0 1 5 0 0}$

Road Name (I - 7): -

Vicinity (I - 9) $\mathbf{5 . 4}$ MI N JCT. U.S. 5

Hydrologic Unit Code: $\mathbf{0 1 0 8 0 1 0 7}$

Longitude (i - 17; nnnnn.n) $\mathbf{7 2 3 7 0}$

\section{Select Federal Inventory Codes}

FHWA Structure Number $(I-8) \underline{\mathbf{2 0 0 0 1 5 0 0 0 5 1 3 0 5}}$

Maintenance responsibility $(I-21 ; n n) \_$01_ Maximum span length $(I-48 ; n n n n) \underline{\mathbf{0 0 8 2}}$

Year built (I - 27; YYYY) 1952

Structure length (I - 49; nnnnnn) $\underline{000084}$

Average daily traffic, ADT (I - 29; nnnnnn) $\underline{004690}$ Deck Width (I- 52; nn.n) 352

Year of ADT (I - 30; YY) $\mathbf{9 2}$

Channel \& Protection $(I-61 ; n) \underline{8}$

Opening skew to Roadway $(I-34 ; n n) \quad \mathbf{0 0}$

Waterway adequacy $(I-71 ; n)$

Operational status $(I-41 ; X)$ A

Underwater Inspection Frequency $(I-92 B ; X Y Y) \_\mathbf{N}$

Structure type (I - 43; nnn) $\mathbf{3 0 2}$

Year Reconstructed $(I$ - 106) 1972

Approach span structure type $(I-44 ; n n n) \quad \mathbf{0 0 0}$ Clear span (nnn.nft) _ _

Number of spans (I - 45; nnn) $\mathbf{0 0 1}$

Vertical clearance from streambed (nnn.n ft) $\underline{\mathbf{1 2 . 0}}$

Number of approach spans (I - 46; nnnn) $\mathbf{0 0 0 0}$ Waterway of full opening $\left(n n n . n \mathrm{ft}^{2}\right)$

Comments:

Structural inspection report (11/03/93): Single span steel beam bridge with asphalt surface and approaches. Not very much of the concrete abutment stems are in view. They have very minor hairline cracks and stains. There is riprap in front of them. The waterway has a fairly straight alignment through the structure. The streambed consists of stone and gravel, with numerous large boulders upstream. The West river is roughly $200 \mathrm{ft}$ downstream. 


\section{Bridge Hydrologic Data}

Is there hydrologic data available? $\underline{\mathbf{N}}$ if No, type ctrl-n $h \quad$ VTAOT Drainage area $\left(m i^{2}\right)$ : -

Terrain character:

Stream character \& type: -

Streambed material:

Discharge Data (cfs):



Record flood date $(M M / D D / Y Y):-{ }^{\prime}-$
Estimated Discharge $(c f s):-$

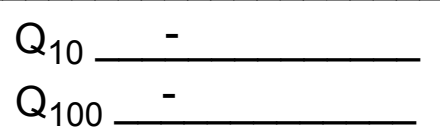

$\mathrm{Q}_{25}$

Water surface elevation $(f t):-$ $(\mathrm{ft} / \mathrm{s}):$

Ice conditions (Heavy, Moderate, Light) : -

Debris (Heavy, Moderate, Light):

The stage increases to maximum highwater elevation (Rapidly, Not rapidly):

The stream response is (Flashy, Not flashy):

Describe any significant site conditions upstream or downstream that may influence the stream's stage: -

Watershed storage area (in percent):

The watershed storage area is: - (1-mainly at the headwaters; 2- uniformly distributed; 3-immediatly upstream oi the site)

Water Surface Elevation Estimates for Existing Structure:

\begin{tabular}{|l|l|l|l|l|l|}
\hline Peak discharge frequency & $Q_{2.33}$ & $Q_{10}$ & $Q_{25}$ & $Q_{50}$ & $Q_{100}$ \\
Water surface elevation (ft)) & - & - & - & - & - \\
Velocity (ft/sec) & - & - & - & - & - \\
\hline
\end{tabular}

Long term stream bed changes: -

Is the roadway overtopped below the $\mathrm{Q}_{100}$ ? (Yes, No, Unknown): $\mathbf{U}$ Frequency: -

Relief Elevation (ft):

Discharge over roadway at $Q_{100}\left(f^{3} / \mathrm{sec}\right)$ :

Are there other structures nearby? (Yes, No, Unknown):

Upstream distance (miles):

Town: If No or Unknown, type ctrl-n os

Highway No. : Structure No. : Year Built:

Clear span (ft): Clear Height $(f t)$ : Full Waterway $\left(f^{2}\right)$ : 
Downstream distance (miles): Town: Year Built:

Highway No. : Structure No. : Structure Type:

Clear span (ft): Clear Height $(f t)$ : Full Waterway $\left(f^{2}\right)$ : -

Comments:

\section{USGS Watershed Data}

Watershed Hydrographic Data

Drainage area $(D A)$

Watershed storage (ST)

Bridge site elevation $\mathbf{2 7 6}$ $\mathrm{mi}^{2}$ Lake/pond/swamp area 0.15 $\mathrm{mi}^{2}$

Main channel length $\mathbf{5 . 2 3}$ $\%$ $10 \%$ channel length elevation $\quad \mathbf{4 5 3}$ $\mathrm{ft} \quad 85 \%$ channel length elevation $\mathrm{ft}$

Main channel slope $(S)$

(S) 236.05 $\mathrm{ft} / \mathrm{mi}$

Watershed Precipitation Data

Average site precipitation in Average headwater precipitation in

Maximum 2yr-24hr precipitation event $(124,2)$ in

Average seasonal snowfall (Sn) $\mathrm{ft}$ 


\section{Bridge Plan Data}

Are plans available? $\underline{\mathbf{Y}}$ If no, type ctrl-n pl Date issued for construction (MM/YYYY): $\mathbf{1 2} / \mathbf{1 9 6 9}$ Project Number Minimum channel bed elevation: $\underline{\mathbf{4 8 4}} .5$

Low superstructure elevation: USLAB DSLAB USRAB DSRAB Benchmark location description:

$-$

Reference Point (MSL, Arbitrary, Other): Arbitrary $\quad$ Datum (NAD27, NAD83, Other): Arbitrary Foundation Type: 1

If 1 : Footing Thickness $\mathbf{2 . 0} \quad$ Footing bottom elevation: $\underline{\mathbf{4 7 8 . 0}}$

If 2: Pile Type: ___ (1-Wood; 2-Steel or metal; 3-Concrete) Approximate pile driven length: -

If 3: Footing bottom elevation: -

Is boring information available? $\mathbf{N}$ If no, type ctrl-n bi Number of borings taken: _-

Foundation Material Type: $\mathbf{3}$ (1-regolith, 2-bedrock, 3-unknown)

Briefly describe material at foundation bottom elevation or around piles:

NO FOUNDATION MATERIAL INFORMATION

Comments:

Other elevation points: 1) above left abutment end finished grade elevation 499.56. 2) above right abutment end finished grade elevation 499.27. Plans are for reconditioning of the pavement. 


\section{Cross-sectional Data}

Is cross-sectional data available? $\mathbf{N}$ If no, type ctrl-n xs

Source (FEMA, VTAOT, Other)? -

Comments:

\section{NO CROSS SECTION INFORMATION}

\begin{tabular}{|l|l|l|l|l|l|l|l|l|l|l|l|}
\hline Station & - & - & - & - & - & - & - & - & - & - & - \\
\hline Feature & - & - & - & - & - & - & - & - & - & - & - \\
\hline $\begin{array}{l}\text { Low cord } \\
\text { elevation }\end{array}$ & - & - & - & - & - & - & - & - & - & - & - \\
\hline $\begin{array}{l}\text { Bed } \\
\text { elevation }\end{array}$ & - & - & - & - & - & - & - & - & - & - & - \\
\hline $\begin{array}{l}\text { Low cord to } \\
\text { bed length }\end{array}$ & - & - & - & - & - & - & - & - & - & - & - \\
\hline Station & - & - & - & - & - & - & - & - & - & - & - \\
\hline Feature & - & - & - & - & - & - & - & - & - & - & - \\
\hline $\begin{array}{l}\text { Low cord } \\
\text { elevation }\end{array}$ & - & - & - & - & - & - & - & - & - & - & - \\
\hline $\begin{array}{l}\text { Bed } \\
\text { elevation }\end{array}$ & - & - & - & - & - & - & - & - & - & - & - \\
\hline $\begin{array}{l}\text { Low cord to } \\
\text { bed length }\end{array}$ & - & - & - & - & - & - & - & - & - & - & - \\
\hline
\end{tabular}

Source (FEMA, VTAOT, Other)?

Comments: NO CROSS SECTION INFORMATION

\begin{tabular}{|l|l|l|l|l|l|l|l|l|l|l|l|}
\hline Station & - & - & - & - & - & - & - & - & - & - & - \\
\hline Feature & - & - & - & - & - & - & - & - & - & - & - \\
\hline $\begin{array}{l}\text { Low cord } \\
\text { elevation }\end{array}$ & - & - & - & - & - & - & - & - & - & - & - \\
\hline $\begin{array}{l}\text { Bed } \\
\text { elevation }\end{array}$ & - & - & - & - & - & - & - & - & - & - & - \\
\hline $\begin{array}{l}\text { Low cord to } \\
\text { bed length }\end{array}$ & - & - & - & - & - & - & - & - & - & - & - \\
\hline Station & - & - & - & - & - & - & - & - & - & - & - \\
\hline Feature & - & - & - & - & - & - & - & - & - & - & - \\
\hline $\begin{array}{l}\text { Low cord } \\
\text { elevation }\end{array}$ & - & - & - & - & - & - & - & - & - & - & - \\
\hline $\begin{array}{l}\text { Bed } \\
\text { elevation }\end{array}$ & - & - & - & - & - & - & - & - & - & - & - \\
\hline $\begin{array}{l}\text { Low cord to } \\
\text { bed length }\end{array}$ & - & - & - & - & - & - & - & - & - & - & - \\
\hline
\end{tabular}




\section{APPENDIX E: \\ LEVEL I DATA FORM}


U. S. Geological Survey

Bridge Field Data Collection and Processing Form

Qa/Qc Check by: RB Date: $\underline{11 / 1 / 96}$

\section{Structure Number DUMMVT00300005}

Computerized by: $\underline{\mathbf{R B}}$ Date: $11 / 4 / 96$

Reviewd by:

MAI Date: $\underline{5 / 27 / 97}$

\section{A. General Location Descriptive}

1. Data collected by (First Initial, Full last name) R. FLYNN

2. Highway District Number $\mathbf{0 2}$

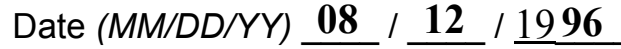

County Windham (025)

Waterway (I - 6) STICKNEY BROOK

Route Number VT30

Mile marker $\mathbf{0 0 1 5 0 0}$

Town Dummerston (18325)

Road Name STICKNEY BROOK ROAD

Hydrologic Unit Code: $\mathbf{0 1 0 8 0 1 0 7}$

3. Descriptive comments:

Located 5.4 miles north of VT 30 intersection with US 5 and 0.05 miles north of TH 47 in Dummerston.

\section{B. Bridge Deck Observations}
4. Surface cover... LBUS 6
RBUS 6
LBDS 6
RBDS 6
Overall 6

(2b us,ds,lb,rb: 1- Urban; 2- Suburban; 3- Row crops; 4- Pasture; 5- Shrub- and brushland; 6- Forest; 7- Wetland)
5. Ambient water surface... US 2
UB 1
DS 2
(1- pool; 2- riffle)

6. Bridge structure type 1 (1- single span; 2- multiple span; 3- single arch; 4- multiple arch; 5-cylindrical culvert; 6- box culvert; or 7- other)
7. Bridge length 84
(feet)
Span length $\mathbf{8 2}$
(feet)
Bridge width $\underline{\mathbf{3 5 . 2}}$ (feet)

\section{Road approach to bridge:}
8. LB 0 RB 0
( 0 even, 1- lower, 2- higher)
9. LB
RB 1
(1-Paved, 2- Not paved)

10. Embankment slope (run / rise in feet / foot):

US left

6.8:1

US right $\quad 3.1: 1$

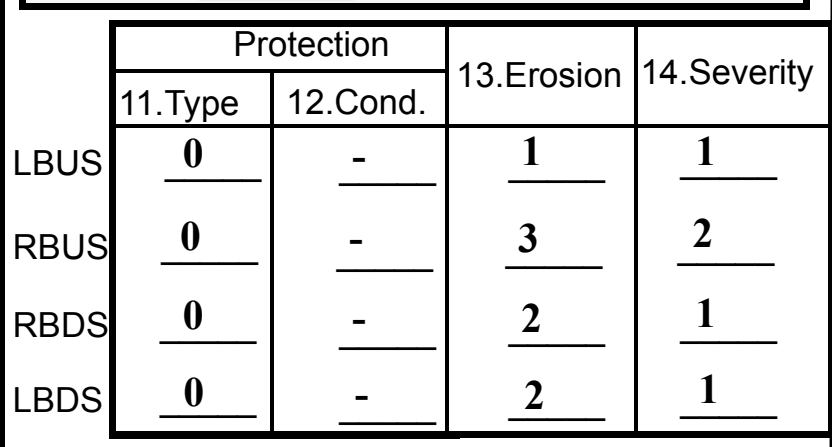

Bank protection types: 0- none; 1- < 12 inches;

2- $<36$ inches; $3-<48$ inches;

4- < 60 inches; 5- wall / artificial levee

Bank protection conditions: 1- good; 2- slumped;

3- eroded; 4- failed

Erosion: 0 - none; 1- channel erosion; 2 -

road wash; 3- both; 4- other

Erosion Severity: 0 - none; 1- slight; 2- moderate; 3- severe

\section{Channel approach to bridge (BF):}

15. Angle of approach: $\mathbf{5}$

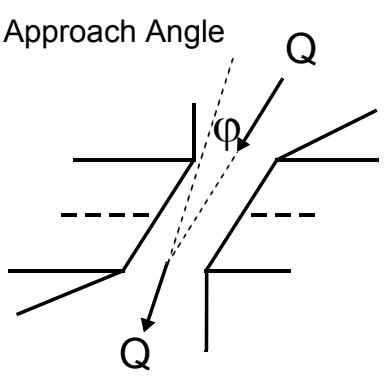

17. Channel impact zone 1:

Where? RB (LB, RB)

Range? 0 feet US

Channel impact zone 2:

Where? RB $(L B, R B)$

Range? 64 feet $\underline{\mathbf{U S}}$ (US, UB, DS) to $\underline{125}$ feet $\underline{\mathbf{U S}}$

Impact Severity: 0- none to very slight; 1-Slight; 2- Moderate; 3- Severe
16. Bridge skew: 5 Bridge Skew Angle

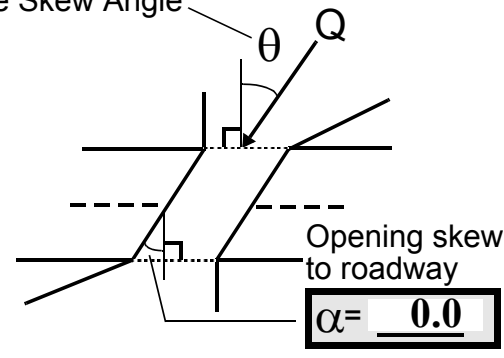

\section{Exist? $\mathbf{Y}(Y$ or $N)$}

Severity 1

US, UB, DS) to $\underline{\mathbf{8 0}}$ feet $\underline{\mathbf{D S}}$

Exist? $\mathbf{Y}(\mathrm{Y}$ or $N)$

Severity $\underline{2}$ 
18. Bridge Type: $\mathbf{3}$

1a- Vertical abutments with wingwalls

1 b- Vertical abutments without wingwalls

2- Vertical abutments and wingwalls, sloping embankment

Wingwalls perpendicular to abut. face

3- Spill through abutments

4- Sloping embankment, vertical wingwalls and abutments

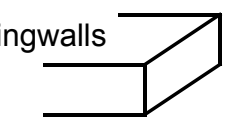

1a with wingwalls

Wingwall angle less than $90^{\circ}$.

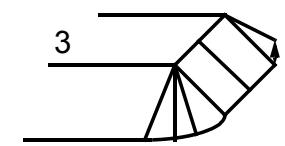$$
\text { . }
$$

19. Bridge Deck Comments (surface cover variations, measured bridge and span lengths, bridge type variations, approach overflow width, etc.)

7. Values are from the VT AOT files. Measured bridge length is $84 \mathrm{ft}$., span length is $82 \mathrm{ft}$., and the bridge width is $34.9 \mathrm{ft}$.

\section{Upstream Channel Assessment}

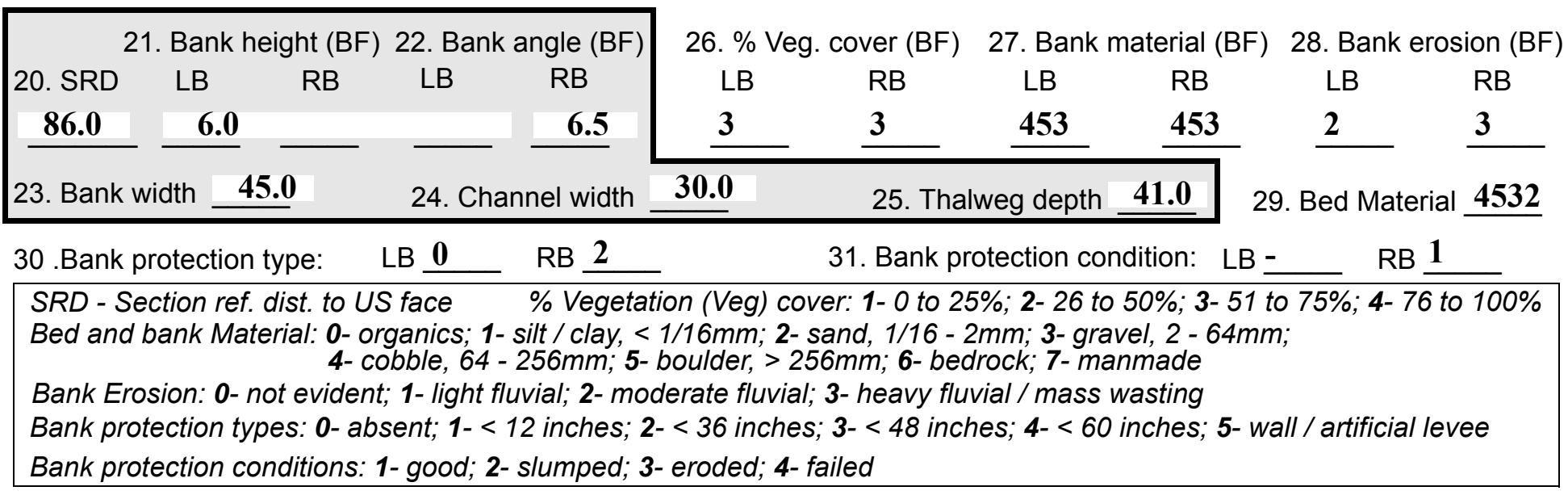

32. Comments (bank material variation, minor inflows, protection extent, etc.):

27. Cobbles and boulders from US are scattered along both banks on both sides.

28. There are exposed tree roots along the right bank and a cut bank at the approach cross section.

30. The right bank protection is from $20 \mathrm{ft}$ US to $64 \mathrm{ft} \mathrm{US}$. 
33.Point/Side bar present? $\mathbf{N}(Y$ or $N$. if $N$ type ctrl-n pb)34. Mid-bar distance: -

35. Mid-bar width: -

36. Point bar extent: feet (US, UB) to feet (US, UB, DS) positioned $\%$ LB to $\% \mathrm{RB}$

37. Material: -

38. Point or side bar comments (Circle Point or Side; Note additional bars, material variation, status, etc.):

NO POINT BARS

39. Is a cut-bank present? $\underline{\mathbf{Y}}$ ( $Y$ or if $N$ type $c t r-n c b)$

40. Where? $\underline{\mathbf{R B}}$ ( $L B$ or $R B)$

41. Mid-bank distance: 95

42. Cut bank extent: 64 feet US (US, UB) to 125 feet $\underline{\mathbf{U S}}$ (US, UB, DS)

43. Bank damage: $\underline{3}$ (1- eroded and/or creep; 2- slip failure; 3- block failure)

44. Cut bank comments (eg. additional cut banks, protection condition, etc.):

Exposed tree roots and the scarring of trees is evident.

\section{Is channel scour present? $\mathbf{N}$ ( $Y$ or if $N$ type ctrl-n cs)}

47. Scour dimensions: Length -

Width -

Depth : -

46. Mid-scour distance: -

48. Scour comments (eg. additional scour areas, local scouring process, etc.):

NO CHANNEL SCOUR

49. Are there major confluences? $\mathbf{N}$

51. Confluence 1: Distance Confluence 2: Distance -

52. Enters on -

Enters on -

54. Confluence comments (eg. confluence name):

NO MAJOR CONFLUENCES
50. How many? -

53. Type(1-perennial; 2- ephemeral)

Type (1-perennial; 2-ephemeral) ( $L B$ or $R B)$

\section{Under Bridge Channel Assessment}

55. Channel restraint (BF)? LB 2

\begin{tabular}{|ccccc}
\hline \multicolumn{2}{|c}{ 56. Height (BF) } & \multicolumn{3}{c}{57 Angle (BF) } \\
LB & RB & LB & RB \\
$\mathbf{2 4 . 0}$ & & & $\mathbf{0 . 5}$ & \\
\hline
\end{tabular}
(1- natural bank; 2- abutment; 3- artificial levee)
58. Bank width (BF)
10.0
59. Channel width (Amb)

\begin{tabular}{lc} 
61. Material (BF) \\
LB & RB \\
$\mathbf{2}$ & $\mathbf{7}$ \\
\hline
\end{tabular}

62. Erosion (BF)

LB RB

$\underline{\mathbf{0}}$

Bed and bank Material: 0- organics; 1- silt / clay, < 1/16mm; 2- sand, 1/16 - 2mm; 3- gravel, 2 - 64mm; 4- cobble, 64 - 256mm; 5- boulder, > 256mm; 6- bedrock; 7- manmade

Bank Erosion: 0- not evident; 1- light fluvial; 2- moderate fluvial; 3- heavy fluvial / mass wasting

64. Comments (bank material variation, minor inflows, protection extent, etc.):

4532

There is a scour hole along the toe of the right spill-through slope from the US bridge face to $15 \mathrm{ft}$ under the bridge. The scour hole is $5 \mathrm{ft}$ wide and $0.5 \mathrm{ft}$ deep. 
65. Debris and Ice Is there debris accumulation?

$(Y$ or $N)$ 66. Where? $\underline{Y}$

(1- Upstream; 2- At bridge; 3- Both)

67. Debris Potential $\underline{3}$

(1- Low; 2- Moderate; 3- High)

68. Capture Efficiency 3

(1-Low; 2- Moderate; 3- High)

69. Is there evidence of ice build-up? 2

Ice Blockage Potential $\underline{Y}$

(1-Low; 2- Moderate; 3- High)

70. Debris and Ice Comments:

1

There is scarring on the tree trunks and roots.

\begin{tabular}{|l|c|c|c|c|c|c|c|c|}
\hline Abutments & $\begin{array}{c}\text { 71. Attack } \\
\angle \text { (BF) }\end{array}$ & $\begin{array}{c}\text { 72. Slope } \angle \\
\text { (Qmax) }\end{array}$ & $\begin{array}{c}\text { 73. Toe } \\
\text { loc. (BF) }\end{array}$ & $\begin{array}{c}\text { 74. Scour } \\
\text { Condition }\end{array}$ & $\begin{array}{c}75 . \text { Scour } \\
\text { depth }\end{array}$ & $\begin{array}{c}\text { 76. Exposure } \\
\text { depth }\end{array}$ & 77. Material & 78. Length \\
\hline LABUT & & $\mathbf{0}$ & $\mathbf{4 5}$ & $\mathbf{2}$ & $\mathbf{0}$ & - & - & $\mathbf{3 0 . 0}$ \\
\hline RABUT & $\mathbf{2}$ & $\mathbf{0}$ & $\mathbf{4 5}$ & & & $\mathbf{2}$ & $\mathbf{1}$ & $\mathbf{6 7 . 0}$ \\
\hline
\end{tabular}

Pushed: $L B$ or RB

Toe Location (Loc.): 0- even, 1- set back, 2- protrudes

Scour cond.: 0- not evident; 1- evident (comment); 2- footing exposed; 3-undermined footing; 4- piling exposed; 5- settled; 6- failed

Materials: 1- Concrete; 2- Stone masonry or drywall; 3- steel or metal; 4- wood

79. Abutment comments (eg. undermined penetration, unusual scour processes, debris, etc.):

0.5

0

2

Approximately $2 \mathrm{ft}$. of the top of each concrete abutment is showing. There is type- 2 granite placed at an angle in front of the abutments down to the water that acts as a spill through slope. There is a scour hole along the bottom of the right spill through slope.

80. Wingwalls:

Exist? Material? Scour Scour Exposure $\begin{aligned} & 81 . \\ & \text { Angle? Length? }\end{aligned}$ Condition? depth? depth?

USLWW:

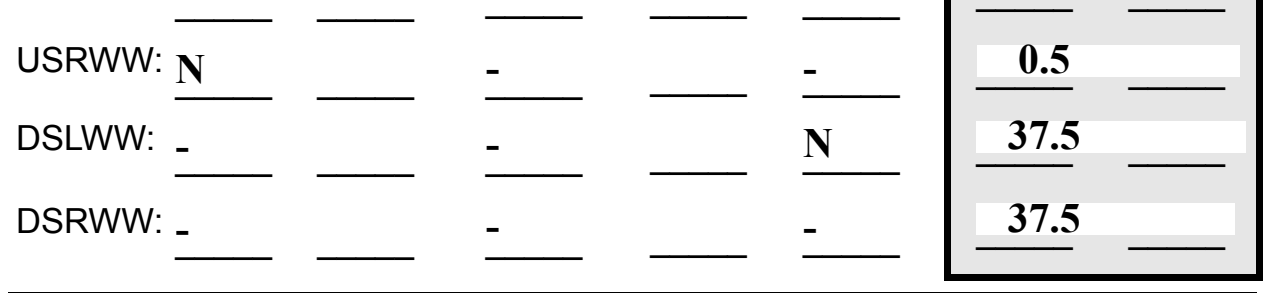

Wingwall materials: 1- Concrete; 2- Stone masonry or drywall; 3- steel or metal; 4- wood

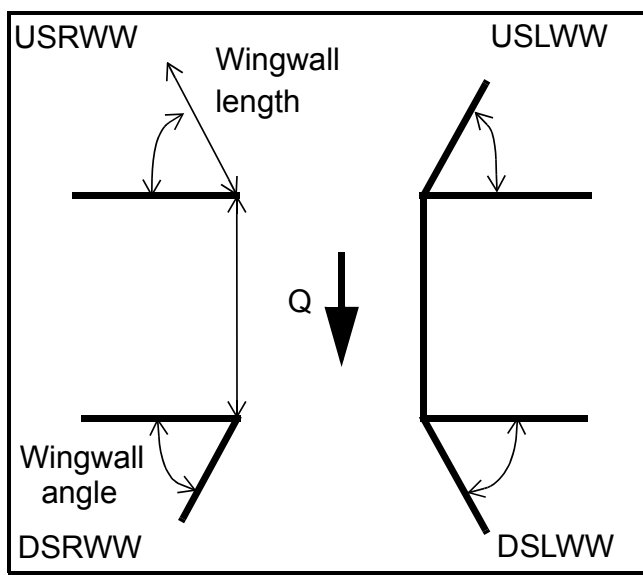

82. Bank / Bridge Protection:

\begin{tabular}{|l|l|l|l|l|l|l|l|c|}
\hline Location & USLWW & USRWW & LABUT & RABUT & LB & RB & DSLWW & DSRWW \\
\hline Type & - & - & N & - & - & - & $\mathbf{1}$ & $\mathbf{1}$ \\
\hline Condition & N & - & - & - & - & - & $\mathbf{1}$ & $\mathbf{1}$ \\
\hline Extent & - & - & - & - & - & $\mathbf{2}$ & $\mathbf{2}$ & - \\
\hline
\end{tabular}

Bank / Bridge protection types: 0- absent; 1- < 12 inches; 2- < 36 inches; 3- < 48 inches; 4- < 60 inches; 
83. Wingwall and protection comments (eg. undermined penetration, unusual scour processes, etc.):

-
-
-
-
-
-
-
-
-
-

\section{Piers:}

84. Are there piers? On (Y or if $N$ type ctrl-n pr)

\begin{tabular}{|l|l|l|l|l|l|l|l|}
\hline \multirow{2}{*}{$\begin{array}{l}85 . \\
\text { Pier no. }\end{array}$} & \multicolumn{3}{|c|}{ width (w) feet } & \multicolumn{3}{c|}{ elevation (e) feet } \\
\cline { 2 - 9 } & w1 & w2 & w3 & e@w1 & e@w2 & e@w3 \\
\hline Pier 1 & - & - & - & - & - & - \\
\hline Pier 2 & - & - & - & - & - & - \\
\hline Pier 3 & - & - & - & - & - & - \\
\hline Pier 4 & - & - & - & - & - & - \\
\hline
\end{tabular}

\begin{tabular}{|l|l|l|l|l|}
\hline Level 1 Pier Descr. & \multicolumn{1}{|c|}{1} & \multicolumn{1}{|c|}{2} & \multicolumn{1}{|c|}{3} & \multicolumn{1}{|c|}{4} \\
\hline 86. Location (BF) & the US & lier & cracke & A $\mathbf{f ~ f t ~}$ \\
\hline 87. Type & right & brid & d in & by 2 \\
\hline 88. Material & bank & ge. & area & ft by \\
\hline 89. Shape &, & The & s and & $\mathbf{2} \mathbf{f t}$ \\
\hline 90. Inclined? & there & con- & is & sec- \\
\hline 91. Attack $\angle$ (BF) & is a & crete & act- & tion \\
\hline 92. Pushed & con- & has & ing & of \\
\hline 93. Length (feet) & - & - & - & - \\
\hline 94. \# of piles & crete & bro- & as & con- \\
\hline 95. Cross-members & rem- & ken & bank & crete \\
\hline 96. Scour Condition & nant & away & pro- & is in \\
\hline 97. Scour depth & of an & and & tec- & the \\
\hline 98. Exposure depth & ear- & is & tion. & river \\
\hline
\end{tabular}

LFP, LTB, LB, MCL, MCM, MCR, RB, RTB, RFP

1- Solid pier, 2- column, 3- bent

1-Wood; 2- concrete; 3- metal; 4- stone

1- Round; 2- Square; 3- Pointed

Y-yes; $N$ - no

$L B$ or $R B$

0- none; 1- laterals; 2- diagonals; 3- both

0- not evident; 1- evident (comment);

2- footing exposed; 3- piling exposed;

4- undermined footing; 5- settled; 6- failed 
99. Pier comments (eg. undermined penetration, protection and protection extent, unusual scour processes, etc.): •

100.

\section{E. Downstream Channel Assessment}

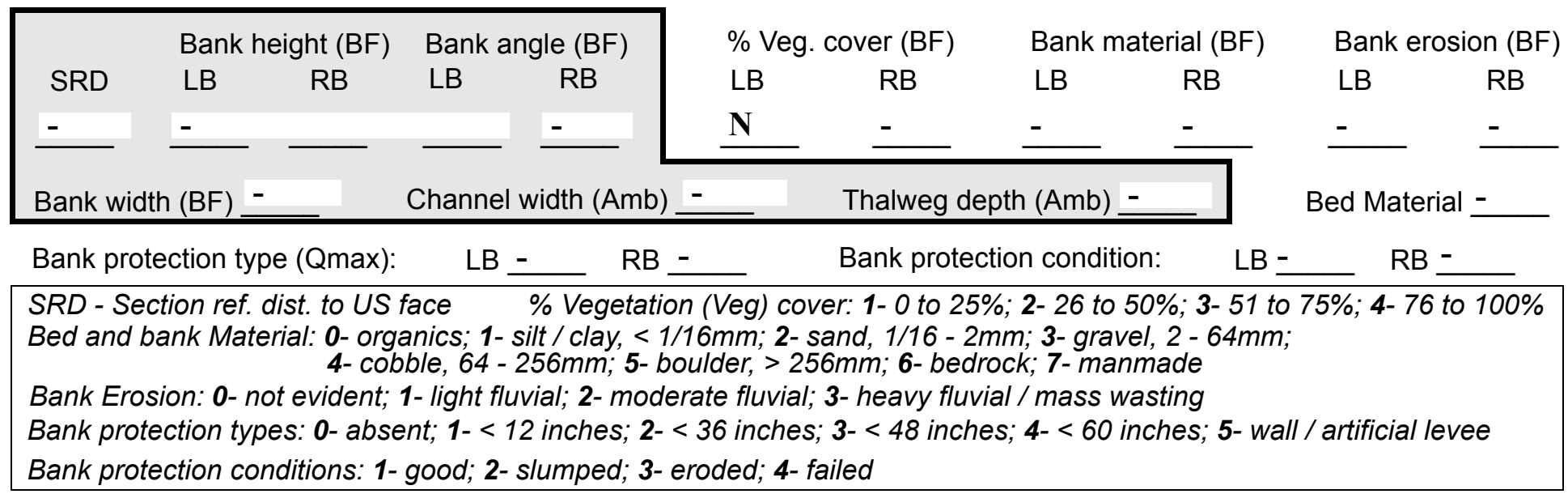

Comments (eg. bank material variation, minor inflows, protection extent, etc.):$$
-
$$

$-$

$-$

$-$

-

$-$

-

$-$

$-$

-

$-$

$-$

-

$-$

$-$

\section{Is a drop structure present? __ ( $Y$ or $N$, if $N$ type ctrl-n ds) 102. Distance: ___ feet}

103. Drop: __ feet 104. Structure material: __ (1- steel sheet pile; 2- wood pile; 3- concrete; 4- other)

105. Drop structure comments (eg. downstream scour depth):

-

-

$-$

-

- 
106. Point/Side bar present? (Y or $N$. if $N$ type ctrl-n pb)Mid-bar distance:

Mid-bar width: -

Point bar extent: feet -

(US, UB, DS) to feet (US, UB, DS) positioned $\%$ LB to $\% \mathrm{RB}$ Material:

Point or side bar comments (Circle Point or Side; note additional bars, material variation, status, etc.):

Is a cut-bank present? - (Y or if $N$ type ctrl-n $c b)$ Where? NO (LB or RB) Mid-bank distance: PIE Cut bank extent: RS feet__ (US, UB, DS) to feet (US, UB, DS)

Bank damage: (1- eroded and/or creep; 2- slip failure; 3- block failure)

Cut bank comments (eg. additional cut banks, protection condition, etc.):

Is channel scour present? ( $Y$ or if $N$ type ctrl-n cs) Width 430 Depth: 430 Scour dimensions: Length 3

Scour comments (eg. additional scour areas, local scouring process, etc.): 425

0

0

Are there major confluences? Confluence 1: Distance West Confluence 2: Distance $\underline{\mathbf{1 8 0} \mathbf{f t}}$ - $\quad$ (Y or if $N$ type ctrl-n mc) Enters on Rive ( $L B$ or $R B$ ) Enters on DS (LB or RB) Mid-scour distance: $\mathbf{3}$

Positioned $\mathbf{2}$ $\%$ LB to $\underline{2}$ $\% \mathrm{RB}$ Confluence comments (eg. confluence name):

the DS face of the bridge. The Stickney Brook has formed a delta where it meets the West River. The deposited material has narrowed the West River by half the width that is immediately US. There is natural bank protec-

\section{F. Geomorphic Channel Assessment}

107. Stage of reach evolution tio
1- Constructed

2- Stable

3- Aggraded

4- Degraded

5- Laterally unstable

6- Vertically and laterally unstable 
108. Evolution comments (Channel evolution not considering bridge effects; See HEC-20, Figure 1 for geomorphic descriptors):

$n$, consisting of large rock, along the base of both the left and right banks for approximately $25 \mathrm{ft}$ DS. 


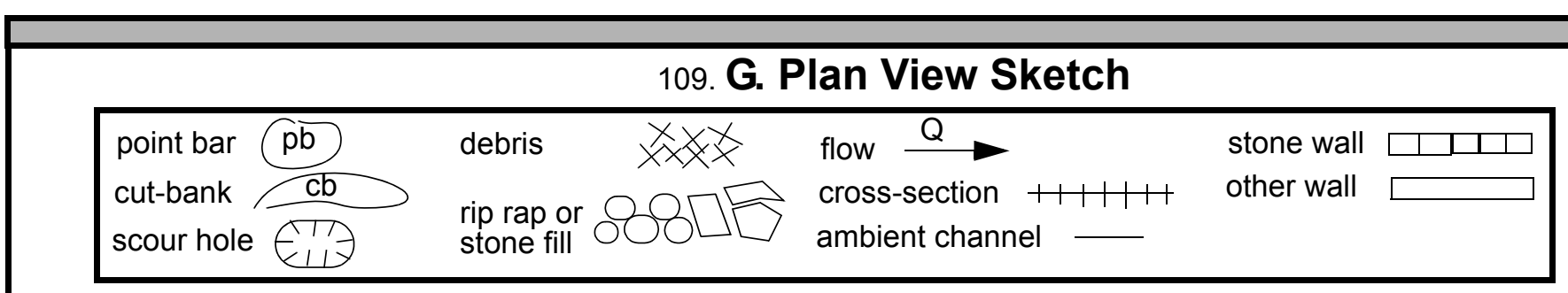


APPENDIX F:

SCOUR COMPUTATIONS 


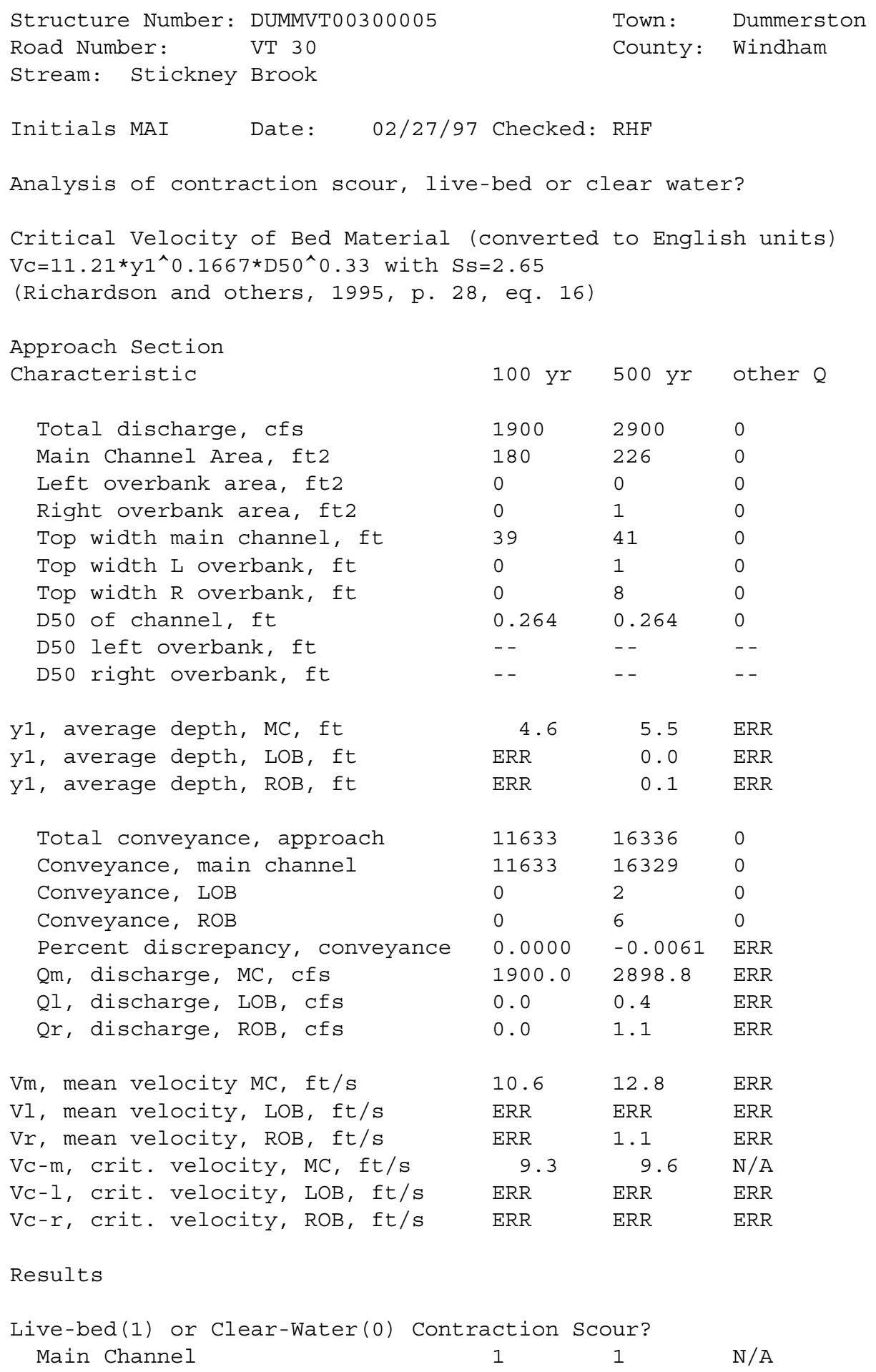


Live-Bed Contraction Scour

Laursen's Live Bed Contraction Scour

$\mathrm{Y} 2 / \mathrm{Y} 1=(\mathrm{Q} 2 / \mathrm{Q} 1)^{\wedge}(6 / 7) *(\mathrm{~W} 1 / \mathrm{W} 2)^{\wedge}(\mathrm{k} 1)$

ys $=$ y $2-y \_b r i d g e$

(Richardson and others, 1995, p. 30, eq. 17 and 18)

\begin{tabular}{|c|c|c|c|c|c|c|}
\hline & \multicolumn{2}{|l|}{ Approach } & \multicolumn{3}{|c|}{ Bridge } & \multirow[b]{2}{*}{ Other Q } \\
\hline Characteristic & $100 \mathrm{yr}$ & $500 \mathrm{yr}$ & Other $Q$ & $100 \mathrm{yr}$ & $500 \mathrm{yr}$ & \\
\hline Q1, discharge, cfs & 1900 & 2900 & 0 & 1900 & 2900 & 0 \\
\hline Total conveyance & 11633 & 16336 & 0 & 11918 & 18842 & 0 \\
\hline Main channel conveyance & 11633 & 16329 & 0 & 11918 & 18842 & 0 \\
\hline Main channel discharge & 1900 & 2899 & ERR & 1900 & 2900 & ERR \\
\hline Area - main channel, ft2 & 180 & 226 & 0 & 176.2 & 240.6 & 0 \\
\hline (w1) channel width, ft & 39 & 41 & 0 & 41.9 & 44 & 0 \\
\hline (Wp) cumulative pier width, ft & 0 & 0 & 0 & 0 & 0 & 0 \\
\hline W1, adjusted bottom width(ft) & 39 & 41 & 0 & 41.9 & 44 & 0 \\
\hline D50, ft & 0.264 & 0.264 & 0.264 & & & \\
\hline w, fall velocity, ft/s (p. 32) & 4.2 & 4.2 & 0 & & & \\
\hline y, ave. depth flow, ft & 4.62 & 5.51 & $\mathrm{~N} / \mathrm{A}$ & 4.21 & 5.47 & ERR \\
\hline S1, slope EGL & 0.0398 & 0.0484 & 0 & & & \\
\hline $\mathrm{P}$, wetted perimeter, $\mathrm{MC}$, ft & 43 & 46 & 0 & & & \\
\hline R, hydraulic Radius, ft & 4.186 & 4.913 & ERR & & & \\
\hline$V^{*}$, shear velocity, ft/s & 2.316 & 2.767 & $\mathrm{~N} / \mathrm{A}$ & & & \\
\hline $\mathrm{V} * / \mathrm{w}$ & 0.551 & 0.659 & ERR & & & \\
\hline $\begin{array}{l}\text { Bed transport coeff., } \mathrm{kl},(0.59 \text { if } \\
\mathrm{k} 1\end{array}$ & $\begin{array}{l}\mathrm{V}^{*} / \mathrm{w}<0.5 \\
0.64\end{array}$ & $\begin{array}{l}0.64 \text { if } \\
0.64\end{array}$ & $\begin{array}{c}5<\mathrm{V} * / \mathrm{W}<2 \\
0\end{array}$ & ; 0.69 if & $\mathrm{V} * / \mathrm{w}>2.0$ & $0 \mathrm{p} .33)$ \\
\hline $\mathrm{y}^{2}$, depth in contraction, ft & 4.41 & 5.27 & ERR & & & \\
\hline ys, scour depth, ft (y2-y_bridge) & 0.20 & -0.20 & $\mathrm{~N} / \mathrm{A}$ & & & \\
\hline \multicolumn{7}{|l|}{ ARMORING } \\
\hline D90 & 0.825 & 0.825 & 0 & & & \\
\hline D95 & 1.11 & 1.11 & 0 & & & \\
\hline Critical grain size,Dc, ft & 0.6871 & 0.7590 & $\mathrm{ERF}$ & & & \\
\hline Decimal-percent coarser than Dc & 0.12 & 0.109 & 0 & & & \\
\hline depth to armoring, ft & 15.12 & 18.61 & ERR & & & \\
\hline \multicolumn{7}{|l|}{ Abutment Scour } \\
\hline \multirow{2}{*}{\multicolumn{7}{|c|}{$\begin{array}{l}\text { Froehlich's Abutment Scour } \\
\text { Ys/Y1 }=2.27 * \mathrm{~K} 1 * \mathrm{~K} 2 *\left(\mathrm{a}^{\prime} / \mathrm{Y} 1\right)^{\wedge} 0.43 \mathrm{Fr}^{\wedge} 0.61+1 \\
\text { (Richardson and others, 1995, p. 48, eq. 28) }\end{array}$}} \\
\hline & & & & & & \\
\hline & \multicolumn{2}{|c|}{ Left Abutment } & \multicolumn{4}{|c|}{ Right Abutment } \\
\hline Characteristic & $100 \mathrm{yr} Q$ & 500 yr Q & Other $Q$ & $100 \mathrm{yr} Q$ & 500 yr Q & Othe \\
\hline
\end{tabular}




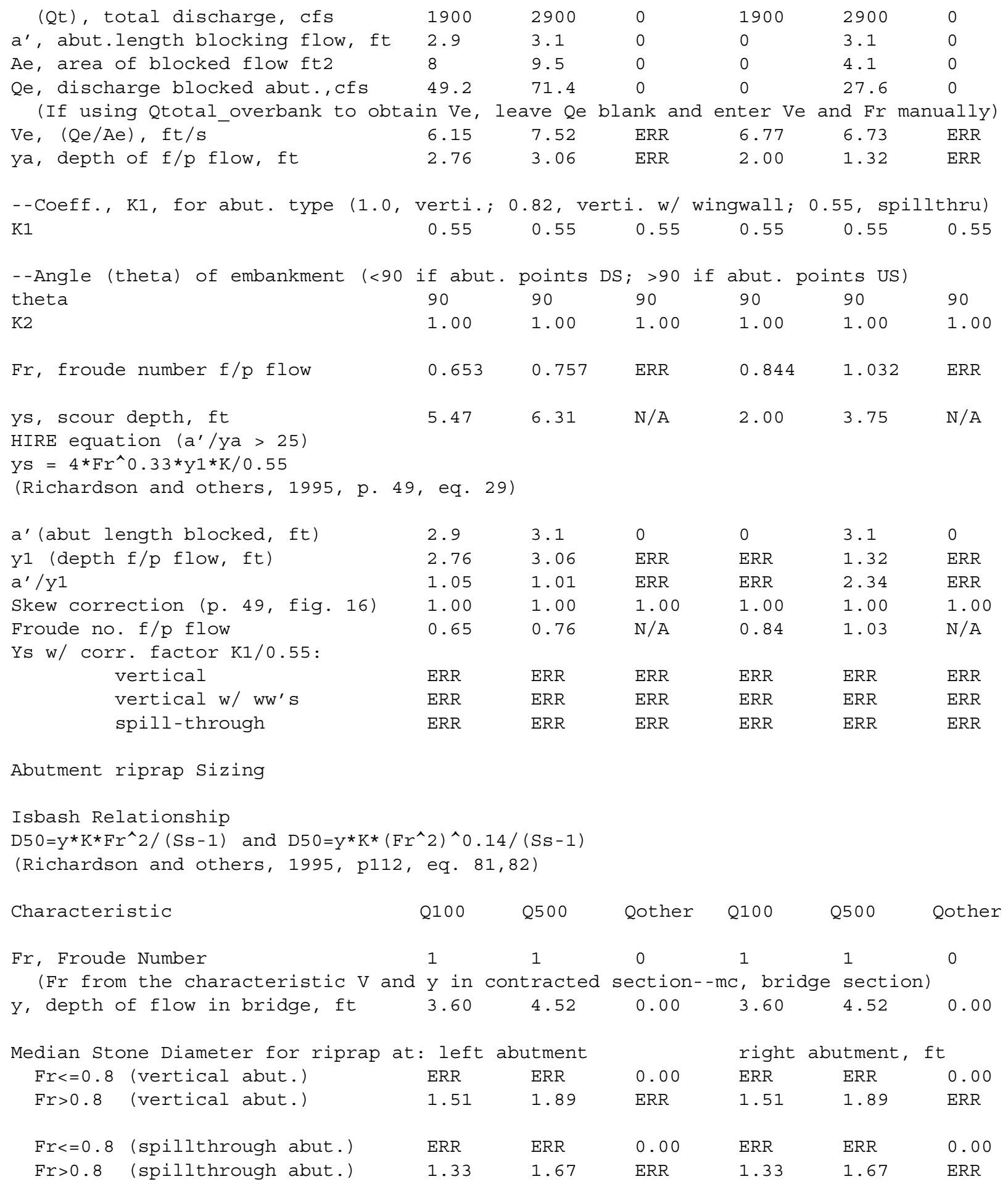


